\title{
Kıssa-i Mûsâ anlatıları üzerine değerlendirmeler ve müellifi bilinmeyen bir Kıssa-i Mûsâ örneği
}

\section{Halime ÇAVUŞOĞLU1}

\begin{abstract}
APA: Çavuşoğlu, H. (2020). Kıssa-i Mûsâ anlatıları üzerine değerlendirmeler ve müellifi bilinmeyen bir Kıssa-i Mûsâ örneği. RumeliDE Dil ve Edebiyat Araştırmaları Dergisi, (18), 206-229. DOI: 10.29000/rumelide.705583.
\end{abstract}

$\ddot{\mathbf{O} z}$

Klasik Türk edebiyatının kaynaklarından biri olan Kur'an kıssaları, insanları doğru yola sevk etmek, hidayete ulaştırmak için önemli vasıtalardır. Kur'an'da öz olarak bulunan bu kıssalar, zamanla farkl kaynaklardan da beslenerek genişlemiş, edebiyatımızın temel malzemesi olmuşlardır. Hz. Yusuf, Hz. İbrahim, Hz. Süleyman, Zülkarneyn kıssaları edebiyatımızda çokça işlenmiş, müstakil eserlere de konu olmuş kıssalardır. Bu kıssalardan bir tanesi de Hz. Musa kıssasıdır. Hz. Musa kıssası, hem manzum hem de mensur eserlerin muhtevalarına kaynaklık etmiş, edebiyatımızda bu kıssa etrafında muhtelif eserler oluşturulmuştur. Çalışmamıza konu olan Kıssa-i Mûsâ metni, Amasya Beyazıt İl Halk Kütüphanesi o5 Ba 509/4 numarasıyla kayıtlı bir mecmuada bulunmaktadır. Müellifi belli olmayan metin, Hz. Musa kıssasının bir bölümü olan Hz. Musa'nın Tûr Dağı'nda Allah ile konuşması hadisesini konu almaktadır. Hz. Musa kıssası içerisinde yer alan bu bölüm müstakil eserlere "Münâcât-ı Mûsâ (AS)" başlığıyla konu olmuştur. 22 varaktan oluşan bu metin baştan sona kadar Hz. Musa'nın Allah'a münacatı ve Allah'ın emir ve yasakları konusu etrafında şekillenmiştir. Eski Anadolu Türkçesinin dil hususiyetlerini gösteren metinde karşılıklı konuşma üslubu ve anlaşılır bir dil kullanılmıştır. Halkın anlayabileceği bir dille yazılan metinin dinî-didaktik yönü de ağır basmaktadır. Çalışmada öncelikli olarak Kur'an kıssaları hakkında bilgi verilecek, daha sonra edebiyatımızda Hz. Musa kıssasına yer veren bazı temel eserler ve bu eserlerde yer alan hikâyeler tanıtılacaktır. Akabinde çalışma konusu olan Kıssa-i Mûsâ metni tanıtılarak kıssanın transkripsiyonlu metni verilecektir.

Anahtar kelimeler: Klasik Türk edebiyatı, kıssa, münâcât, Kıssa-i Musa.

\section{Evaluations on Kıssa-i Mûsâ narratives and an example of Kıssa-i Mûsâ}

\begin{abstract}
Qur'anic stories, which are one of the sources of classical Turkish literature, are important tools to guide people to the right path and to guide them. These stories, which are essentially found in the Qur'an, have expanded by feeding from different sources over time and have become the basic material of our literature. The stories of Yusuf, İbrahim, Süleyman and Zülkarneyn are the stories that have been widely studied in our literature and have been the subject of individual works. One of these stories is the story of Moses. The story of Moses has been the source of both verse and prose works, and various works have been created around this story in our literature. The text of Kissa-i Mûsâ, which is the subject of our study, is registered in a magazine registered with the number of Amasya Beyazit Provincial Public Library 05 Ba 509/4. The text of which the author is uncertain is the subject of the conversation of Moses, who is part of the story of Musa, with Allah on the Mount
\end{abstract}

$1 \quad$ Dr. Öğr. Üyesi, Erzurum Teknik Üniversitesi, Edebiyat Fakültesi, Türk Dili ve Edebiyatı Bölümü (Erzurum, Türkiye), cavusogluhalime@erzurum.edu.tr, ORCID ID: 0000-0001-8717-5679 [Makale kaylt tarihi: 31.01.2020-kabul tarihi: 20.03.2020; DOI: 10.29000/rumelide.705583] 
Tur. This section in the story of Moses has become the subject of individual works with the title "Münâcât-ı Mûsâ (AS)". This text, consisting of 22 leaves, is shaped around the subject of Moses' love to Allah and Allah's commands and prohibitions. In the text that shows the language features of Old Anatolian Turkish, a mutual speaking style and a clear language are used. The religious-didactic aspect of the text, written in a language that the public can understand, also outweighs. In the study, firstly, information about the stories of the Qur'an will be given, and then some basic works that include the story of Moses in our literature and the stories in these works will be introduced. Subsequently, the text of Kıssa-i Mûsâ, which is the subject of the study, will be introduced and transcribed text will be provided.

Keywords: Classical Turkish literature, story, pleading, Kıssa-i Musa.

\section{Giriş}

Klasik Türk edebiyatının en önemli kaynaklarından biri olan Kur'an kıssaları kimi zaman metinlerde yeri geldiğinde kullanılarak metin içinde bir çağrışım dünyası oluşturmaya, metne anlam derinliği katmaya yardımcı olur kimi zaman da bir edebi metnin baştan sona konusu olarak manzum veya mensur bir şekilde farklı edebi türlerin oluşmasına zemin hazırlarlar. Kur'an kıssaları, kaynaklarda kapsamlı bir şekilde şöyle tanıtılmaktadır.

"Tarihin derinliklerinde kaybolmuş, unutulmuş veya bazı izleri insanlığın hafızasında varlığını koruyabilmiş, her zaman için geçerli mutlak hakikatleri, yüksek dinî değerleri, yönlendirme, teşvik gibi unsurları, başka kıssalarda bulunmayan bir şekilde ihtiva eden tarihi olayların, sözce kendisinden daha doğru bir kimsenin bulunmadığı Allah tarafından Kur'an muhataplarına, adeta olaylara yeniden bir canlılık vererek anlatılmasıdır. Ancak hadiseler anlatılırken, Kur'an tarih kitabı olmadığından, teferruat meselelerini; lüzumsuz kısımlarını terketmiş, -bir benzetme yapacak olursak makaslamış- sadece Kur'an'ın hidayet rehberi oluşuna uygun bir şekilde muhatapları irşad edip aydınlatacak kısımlarını anlatmıştır. Bu anlatma şekli de olayların aslı Cenab-ı Hakk'ın her şeyi kuşatan ilmiyle adım adım izlenerek vakanın aslında herhangi bir değişiklik yapılmadan ve Kur'an'ın i'caz ve icazına paralel, iktizai hali mutabık olarak muhatapların ibret ve tefekkürüne sunulmasıdır (Şengül, 1994: 134-135)."

"İnsanların ibret almalarını ve hidayete ulaşmalarını sağlamak amacıyla, çoğunlukla zaman ve mekândan soyutlanmış, geçmiş peygamberler ve kavimleri ile veya geçmiş toplumlarla ilgili anlatılan olaylara kıssa denir (Demir, 2003: 73)."

Tanımlarda ve "And olsun onların kıssalarında akıl sahipleri için ibretler vardır. Kur'an, uydurulabilecek bir söz değildir; fakat o, kendinden öncekiler için onay, her şey için detaylı açıklama, iman eden toplum için bir rahmet ve hidayettir (12/111)..$^{2 "}$ ayetinde görüldüğü gibi toplumların ibret alması, doğru yola ulaşması için önemli bir unsur olan Kur'an kıssalarında, "Hz. Adem'in yaratılışından başlayarak Hz. Peygamber'e kadar yaşanılan insanlık serüveni içinde insanın değişmeyen karakter yapısı örneklerle müşahhas bir biçimde sergilenmiştir (Hazer, 2006: 206)."

Kur'an kıssaları, edebi metinlere de konu olmuş, edebiyatımızda bu doğrultuda şekillenen, manzum ve mensur edebi türler oluşmuştur. "Ümmet çağındaki Türk Edebiyatında hikâye türünün ilk kaynağı, Kur'an'daki kıssalar, dervişler arasında yayılmaya başlayan enbiya ve evliya "menkabe"leri, din ulularının efsaneleştirilmiş kişilikleri çevresinde beliren söylentilerdir (Levend, 1998: 122)." Ümmet

Çalışmada geçen ayetler https://kuran.diyanet.gov.tr/ adresinde yer alan ilgili surelerden alınmıştır.

Adres 
çağı Türk Edebiyatının ilk kaynağı olarak gösterilen Kur'an kıssaları ve bu kıssaların büyük bir çoğunluğunu tutan peygamber kıssaları çevresinde edebiyatımızda geniş bir anlatı geleneği oluşmuştur. $\mathrm{Bu}$ anlatı geleneğinin temelini Kur'an teşkil etmekle beraber Kur'an'da öz bir halde ayrıntıya girmeden yer alan bu kıssalar, zamanla başka din ve kültürlerin etkisiyle de genişleyip zenginleşerek farklı bir boyut kazanmıştır. Bu gelenek çerçevesinde kısas-ı enbiyalar gibi müstakil eserler oluşturulmuştur. Kısas-ı enbiyaların temel kaynağı Kur'an olmakla beraber bu eserler; "Kur'an dışı kaynaklarla genişletilmiş, bu noktada İsrâiliyat denilen Yahudi ve Hristiyan kutsal metinleriyle Yahudi dinî literatüründen (Şahin, 2002: 495)" faydalanılarak meydana getirilmiştir.

Kur'an'ın en uzun ve tek seferde anlatılan kıssası Yusuf Aleyhisselam'ın kıssası iken en çok tekrar edilen kıssası Musa Aleyhisselam'ın kıssasıdır. Bu kıssalar kısas-ı enbiyalar başta olmak üzere müstakil bir şekilde eserlere de konu olmuştur. "Hz. İbrahim, Hz. Yusuf, Hz. Süleyman ve Zülkarneyn kıssaları müstakil eserler olarak yüzyıllar içinde işlenerek belli bir tür özelliği kazanmıştır (Gökcan Türkdoğan, 2010: 65)." Bu kıssaların yanı sıra Hz. Musa kıssası da manzum ve mensur olarak pek çok eserin muhtevasını oluşturmuştur. Edebiyatımızda manzumelerin içerisinde bir teşbih ve telmih unsuru olarak zikredilen Hz Musa, özellikle Tûr Dağı'nda yaşadıkları ve Allah'ın tecellisine mazhar olması; asasının yılana dönüşmesi, Firavun ile mücadelesi, Firavun ve askerlerinin denizde boğulması, Hızır olarak isimlendirilen bilge kul ile yaşadıkları, yed-i beyza mucizesi ile edebi metinlerin içerisinde sıkça anılmaktadır. Bunun yanı sıra Firavun ile mücadelesi, Tûr Dağı ve Allah ile doğrudan konuşması, Hızır ile yaşadıkları mensur veya manzum olarak metinlerde müstakil veya bir eserin içerisinde sıkça işlenmiş mevzulardır. Hz. Musa'nın Tûr Dağı ve Allah'la konuşması hadisesinin anlatıldığı mensur "Kıssa-i Mûsâ" metnine geçmeden önce Kur'an-ı Kerim'de Hz. Musa kıssasının nasıl yer aldığına değinmek yerinde olacaktır.

\section{A. Kur'an-ı Kerim'de Hz. Musa kıssası}

Kur'an'da Hz. Musa kıssası; A'râf Sure'si, Şu'arâ Suresi, Taha Suresi, Neml Suresi, Yunus Suresi, Kasas Suresi, Saffat Suresi, Mümin Suresi, Zuhruf Suresi, Duhan Suresi, Kehf Suresi, İbrahim Suresi, Naziat Suresi, Bakara Suresi'nde geçmektedir. ${ }^{3}$ Çalışmamıza konu olan ve "Kıssa-i Mûsâ" olarak adlandırılan metin Hz. Musa'nın Allah ile doğrudan konuşmasını konu edinmektedir. Bu olay, önce Hz. Musa, Medyen'den eşi ve çocukları ile yola çıkışı ve yolda uzakta gördüğü bir ateşe doğru ilerlediğinde ateşin bulunduğu ağaç yönünden ona seslenilmesi ile vuku bulmuştur. Taha Suresi 9-48. ayetlerinde mevzu şu şekilde zikredilmektedir:

Mûsâ ile ilgili bilgi sana erişti mi? Hani o bir ateş görmüş ve ailesine şöyle demişti: "Siz bekleyin, (şu uzakta) bir ateş bulunduğunu fark ettim; belki ondan size bir kor parçası getiririm veya ateşin başında bir kılavuz bulurum. "Onun yanına geldiğinde kendisine "ey Mûsâ" diye seslenildi. "İyi bil ki ben, evet yalnız ben senin rabbinim; artık pabuçlarını çıkar, çünkü şu anda kutsal vadide, Tuvâ'dasın. Ben seni seçtim, şimdi vahyedilecek olana kulak ver. Kuşkusuz ben, yalnız ben Allah'ım. Benden başka tanrı yoktur. O halde bana kulluk et, beni hatırında tutmak için namaz kıl." "Onun vaktini herkesten gizlemiş olsam da her bir kişinin yapıp ettiğinin karşılığını görmesi için kıyamet mutlaka gelecektir." "Ona inanmayan ve kendi tutkularının peşinden gidenler sakın seni ona inanmaktan alıkoymasın, sonra sen de helâk olursun! Nedir o sağ elindeki ey Mûsâ?" Dedi ki; "O benim asamdır. Ona dayanırım, onunla koyunlarıma yaprak silkelerim, ona başkaca ihtiyaçlarım da var." Allah buyurdu: "Onu yere at ey Mûsâ!"

3 Hz. Musa kıssasının geçtiği sureler hakkında geniș bilgi için bkz. Murat Karaçizmeli, Kur'an'da Geçen Yusuf ve Musa Kıssalarının Benzer ve Farklı Yönleri, Fatih Sultan Mehmet Vakıf Üniversitesi Sosyal Bilimler Enstitüsü Temel İslam Bilimleri Anabilim Dalı Temel İslam Bilimleri Programı, Yüksek Lisans Tezi, İstanbul, 2018. 
Hemen attı. Bir de ne görsün, o akıp giden bir yllan oluvermiş! Allah "Tut onu ve korkma, biz onu hemen eski haline döndüreceğiz." buyurdu. Şimdi de elini koynuna sok, bir hastalık yüzünden olmaksızın, bir başka mucize olarak bembeyaz çıkacaktır. Böylece sana büyük mucizelerimizden bir kısmını göstermiş olalım. Firavun'a git, çünkü o sınırı çok aştı." Mûsâ "Rabbim dedi, "Kalbime genişlik ver. İşimi bana kolaylaştır. Dilimden düğümü çöz. Ki sözümü iyi anlasınlar. Yakınlarımdan birini bana yardımcı ver. Kardeşim Hârûn'u. Onunla gücümü pekiştir. Onu da görevime ortak et. Ta ki seni bol bol tesbih edelim. Ve seni çok analım. Kuşkusuz sen_bizi görmektesin." Allah buyurdu: "Ey Mûsâ! Dileğin kabul edildi. Zaten sana bir kere daha lutufta bulunmuştuk. Hani annene şunu vahyetmiştik: Onu sandığa koy ve ırmağa bırak; böylece ırmak onu kıyıya çıarsın ve benim de düşmanım, onun da düşmanı olan biri onu alsın. (Ey Mûsâ!) Senin üzerine kendimden bir sevgi bıraktım ki (sevilesin), nezaretim altında büyütülüp yetiştirilesin. Hani kız kardeşin onlara gidip de "Ona bakabilecek birini size göstereyim mi? diyordu. Nihayet gözü gönlü şen olsun ve kederlenmesin diye seni annene kavuşturduk. Ve birisini öldürmüştün de seni tasadan kurtarmış, ardından da seni ciddi sınavlardan geçirmiştik. Bu sebeple yıllarca Medyen halkının arasında kaldın, sonra mukadder olduğu üzere buraya geldin, ey Mûsâ! Ben seni kendim için seçip yetiştirdim." "Sen ve kardeşin mucizelerimle gidin; beni anmakta gevşeklik göstermeyin. İkiniz beraber Firavun'a gidin, çünkü o sınırı çok aştı. Yine de ona söyleyeceklerinizi yumuşak bir üslûpla söyleyin, ola ki aklını başına toplar veya içine korku düşer." "Ey rabbimiz!" dediler, "Doğrusu onun bize karşı ileri gitmesinden veya daha da azmasından endişe ediyoruz." Allah buyurdu: "Korkmayın, bilin ki ben sizinle beraberim; işitirim, görürüm. Ona gidip deyin ki: Biz senin rabbinin elçileriyiz. Artık İsrâiloğulları'nı bırak bizimle gelsinler. Onlara eziyet etme. Sana rabbinden bir mucize getirdik. Esenlik doğru yolu izleyenlerin olacaktır. Bize vahyolunmuştur ki azap, asıl, (peygamberleri) yalanlayıp yüz çevirenlerin başına gelecektir (20/9-48)."

$\mathrm{Bu}$ olayın akabinde Hz. Musa ve kardeşi Harun görevlerini yerine getirmek için Mısır'a giderler ve Firavun'u uyarırlar. Onlara inanmayan, onları yalanlayan Firavun ve onun destekçileri yaptıklarından dolayı pek çok bela ile sınansalar da iman etmezler ve Mısır'dan Allah'ın vahyi ile çıkan Musa ve İsrailoğulları'nı takip ederler. Firavun ve adamları Allah'ın inayetiyle ikiye ayrılan denizin içerisinde boğularak ölürler. Bu olaydan sonra İsrailoğulları'nın sorunları ile uğraşan Hz. Musa, Sina Dağı'nda Allah ile konuşmaya gider ve İsrailoğulları'nı da Harun'a bırakır. Hz. Musa, Allah ile otuz günlüğüne görüşmek için sözleşir ve eklenen on gün ile görüşme kırk güne çıkarılır. Çalışmada konu edilen "Kıssai Mûsâ" metninde bu konuşma derinlemesine anlatılmaktadır. Bu mevzu ise A'râf Sûresi'nde şöyle geçmektedir:

Mûsâ ile otuz gece (için) sözleştik ve buna on gece daha ekledik; böylece rabbinin tayin ettiği vakit kırk geceyi buldu. Mûsâ kardeşi Hârûn'a dedi ki: "Kavmimin içinde benim yerime geç, onları ıslah et, bozguncuların yolunu izleme."Mûsâ, tayin ettiğimiz vakitte (Tûr'a) gelip de rabbi onunla konuştuğunda o, Rabbim! Bana görün; sana bakayım" dedi. Rabbi, "Sen beni asla göremezsin, Fakat şu dağa bak; eğer o yerinde durabilirse sen de beni görebilirsin" buyurdu. Rabbi o dağa tecelli edince onu paramparça etti; Mûsâ da bayllıp düştü. Kendine gelince dedi ki: "Seni noksan sıfatlardan tenzih ederim, sana tövbe ettim; ben inananların ilkiyim." Allah, "Ey Mûsâ!" dedi, "Ben, vahiylerimi göndermek ve konuşmakla insanlar arasında sana seçkin bir yer verdim. Sana verdiğimi al ve şükredenlerden ol." Levhalarda Mûsâ için her konuya dair öğüdü ve her şey hakkında gerekli açıklamaları yazdık. (Ve dedik ki:) "Bunlara sımsıkı sarıl; kavmine de o en güzel öğüt ve açıklamalara sarılmalarını emret. Yakında size yoldan çlkmışların yurdunu göstereceğim (7/142-145)." 


\section{B. Musa kıssasının yer aldığı metinlere bir bakış}

Müstakil eserlerde geniş bir biçimde veya bir eserin içerisinde bölümler halinde yer alan Hz. Musa kıssasının, Kısas-ı Enbiyâların içerisinde Hz. Musa'nın doğumundan vefatına kadar bir bütün olarak ele alındığı görülmektedir. Örneğin; Türk edebiyatında çevirilerine en çok rastladığımız Kısas-ı Enbiyâlardan biri olan Sa'lebî'nin Kitâbu 'Arâisü'l-Mecâlis fi Kısasi'l-Enbiyâ4'sında yer alan Musa kıssası 5 Hz. Musa'nın doğumundan vefatına kadar yaşadıklarının ayrıntılı bir anlatımını içermektedir. Kıssada çoğu olay, ravi isimleri zikredilerek anlatılırken Hz. Musa'nın doğumundan vefatına kadarki olaylar bablar şeklinde başlıklandırılarak anlatılmıştır. Kıssanın ilk babı "el-bâbu'l-evvel fi zikri nesebi mûsâ 'aleyhi's-selâm" başlığını taşırken son bab "zikri vefâti mûsâ 'aleyhi's-selâm" başlığını taşımaktadır. Kıssa ayrıntılı bir şekilde incelendiğinde müstakil veya bölüm halinde kaleme alınmış olan Musa kıssalarına da kaynaklık ettiği tespit edilmiştir. Bir diğer kısas-ı enbiya eseri olan Ahmed Cevdet'in Kısas-ı Enbiyâ ve Tevarih-i Hulefấ ${ }^{6}$ adlı eserinde ise Hz. Musa kıssası, müstakil eserlerle ve Sa'lebî'nin eseriyle kıyaslandığında daha özet bir anlatımla dikkatlere sunulmuştur. Kısas-ı enbiyaların dışında Hz. Musa kıssasının dikkat çekici yönlerinin ya da farklı anlatılarının özellikle dinî-tasavvufî nitelikli eserlerde, çoğunlukla öğüt vermek ve yol göstermek amacıyla tekrarlandığı dikkatimizi çekmektedir. Bu eserlerden bazıları ve içerisinde yer alan Hz. Musa kıssasına dayalı anlatılar, küçük hikâyeler bu kıssa hakkında genel bir fikir edinebilmek için şöyle özetlenebilir:

Mevlânâ'nın Mesnevî'sinde Hz. Musa ile ilgili farklı hikâyeler yer almaktadır. Bunlardan ilki "Hz. Musa'nın bir çobanın candan yakarışını hoş görmemesi" hikâyesidir. Bu hikâyede, Hz. Musa aşk ile Allah'ı bir kişi gibi görerek zikreden bir çobanı, küfre varabileceğini söyleyerek azarlar. Bu azarlamanın neticesinde Allah, Musa'yı kulunun aşk halinde olduğunu söyleyerek uyarır. Hz. Musa da çobanı bularak onu aşkı konusunda müjdeler. Bir diğer küçük hikâye "Hastalığımda niçin benim halimi hatrımı sormaya gelmedin? diye Hak Te'âlâ'nın Hz. Mûsâ'ya vahyetmesi" anlatısıdır. Bu hikâyede, Allah'ın has kullarında tecelli ettiği vurgulanmaktadır. "Firavun'un Musa'yı rüyasında görmesi ve onun doğmaması için tedbirlere girişmesi" konulu hikâyede Firavun'un aldığı tedbirlere rağmen Hz. Musa'nın ana rahmine düşmesine engel olamaması anlatılmaktadır. "Musa ve Firavun" hikâyesinde Allah tarafından Musa'yla yarışması için Firavun'a ruhsat verilmesi ve Firavun'un Mısır'ın en iyi sihirbaz kardeşlerini Musa'yla yarışması için çağırması, iki kardeşin Musa'yı sınamak için yaptıkları hile ve sonunda pişmanlıkları anlatılmaktadır. "Bir adamın Musa'dan hayvanların, kuşların dillerini öğrenmeyi istemesi" hikâyesinde cahil bir adamın Musa'dan hayvanların dillerini öğrenmeyi istemesi, Musa'nın buna karşı çıkmasına rağmen hayvanların dilini ona öğretmesi ve adamın bu ilmi kaldıramaması anlatılmaktadır. "Musa ile Firavun" hikâyesinde Hz. Musa'nın Firavun'u imana davet etmesi, Firavun'un inkârcılığı ardından bu daveti eşi Asiye ve veziri Haman ile paylaşması, Asiye'nin bunu bir lütuf, Haman'ın ise bunu bir hadsizlik olarak görmesi, Firavun'un Haman'ın etkisinde kalarak iman etmemesi, daha sonra Mısırda meydana gelen felaketler ve Allah'ın izniyle felaketlerin son bulması anlatılmaktadır. "Hz. Musa'nın güttüğü sürüden bir koyun kaçması" hikâyesinde ise Hz. Musa'nın sürüden kaçan koyuna merhametle davranması anlatılırken bütün peygamberlerin çobanlık ettiğine dair ifadelere yer verilmiş, emirlerin, devlet büyüklerinin sabırlı ve halim olması öğütlenmiştir.

Eser hakında geniş bilgi için bk. Emine Yılmaz; Nurettin Demir; Murat Küçük, Kısas-ı Enbiya, Türk Dil Kurumu Yayınları, Ankara, 2013.

Kıssa metni için bk. Emine Yılmaz vd., age, s. 236-319.

Metin için bk. Mahir İz, Ahmed Cevdet Kısas-ı Enbiyâ ve Tevarih-i Hulefâ, C. 1, Kültür ve Turizm Bakanlı̆̆ı Yayınları, Ankara, 1985. s.19-27.

Mesnevide yer alan hikâyeler için bk. Şefik Can, Mesnevî Hikâyeleri, Ötüken Neşriyat, İstanbul, 2016. s. 132-135; 145-146; 210-216; 222-228; 285-290; 379-391; 563-564. 
Türk Edebiyatının dini-didaktik eserleri içerisinde yer alan ve geniş halk kitlelerine ulaşarak halk tarafından yüzyllarca severek okunan Ahmed Bîcân'a ait Envâru'l-Âşıkîn8'in ikinci babı peygamber kıssalarına ayrılmıştır. Hz. Âdem'den başlayarak Hz. Muhammed'e kadar gelen peygamberlerin kıssalarının yer aldığı bu babda, Hz. Musa kıssasına da yer verilmiştir. Hz. Musa ile ilgili yer alan "Meb'as-i Mûsâ ibni Mişâ 'aleyhi's-selâm" adlı ilk bölümde Allah'ın kullarının neyi yapıp neyi yapmamalarına dair peygamberine vahyetmiş olduğu uyarılar yer almaktadır. Hz. Musa ile ilgili ikinci bölüm ise "Meb'as-i Mûsâ ve Hârûn 'aleyhi's-selâm" başlığını taşımaktadır. Firavun'un doğumuyla başlatılan olaylar Firavun'un Mısır sultanı olması, gördüğü düşün tabiri neticesinde bütün İsrailoğullarının erkek çocuklarını öldürtmesi, Musa'nın bu sıkıntıdan kurtulması ve ona peygamberlik verilmesi, Tûr Dağı'nda Allah ile konuşması, Allah'ın ona bazı mucizeler vermesi, dört yüz yıl ömür süren Firavun'un Musa'nın getirdiklerine inanmaması ve imana gelmemesi, Allah'ın emri ile Mısır'dan çıan Musa ve kavminin peşinden giden Firavun ve askerlerinin boğularak helak olması anlatılmaktadır. Eserin Hz. Musa ile ilgili üçüncü bölümü "Hadîs-i nuzûlü't-tevrâti ve talebü'r-rü'ye" başlığını taşımaktadır. Bu bölümde ise Firavun'un helak olması ile Hz. Musa'nın kavminin Allah'ın emir ve yasaklarının olduğu kitabı getirmesini istemeleri ve Hz. Musa'nın kardeşini kavmine halife koyarak Cebrail vasıtası ile Tûr Dağı'na çıkması, Allah ile konuşması, Tevrat'ın verilmesi, Hz. Musa'nın Allah'ın tecellisine mazhar olması anlatılmaktadır. Bu bölümden sonra yer alan dördüncü bölüm "Fasl" başlıklı bölümdür. Başka eserlerde "Münâcât-ı Mûsâ" olarak başlıklandırılan, Musa kıssası içerisinde bir parça olarak yer alan veya müstakil bir metin olarak da kendini gösteren ve bizim de çalışmamızda temel aldığımız metnin konusuyla ortak olan bir bölümdür. Bu bölümde, Allah'ın kullarına emir ve yasakları ayrıntılı bir şekilde karşılıklı soru-cevap üslubuyla aktarılmaktadır. Eserde yer alan Musa kıssası ile ilgili son bölüm ise "Fasl fimâ kütibe fi't-Tevrât" başlıklıdır. Bu başlık altında ise Allah'ın Hz. Musa'ya vahyettiklerine devam edilmiş ayrıca burada Musa ve Hızır kıssasına, Musa ve çoban kıssasına da değinilmiştir. Bölüm Hz. Musa'nın yüz yirmi yıllık ömrünün sonlanması ile bitirilmiştir.

15. yüzyılda Eşrefoğlu Rûmi tarafından kaleme alınmış, dini-tasavvufi nitelikli bir başka eser olan Müzekki'n-Nüfûs9'ta da Hz. Musa kıssasına ait bazı hikâyeler bulunmaktadır. "Cimrilik ve Cömertlik" başlığı altında yer alan kısa Hz. Musa hikâyesinde Allah'ın kırk yıllık ömrü olan bir kuluna Hz. Musa aracılı̆̆ıyla yirmi yıl zengin yirmi yıl fakir yaşayabileceğini ve sırasıyla bunları tercih etmesi gerektiğini iletmesi ve ilkin zenginliği tercih eden kulun yirmi yıl boyunca malını Allah yolunda harcaması ve yirmi yılın dolması, durumunun Hz. Musa aracılığı ile kula bildirilmesi, kulun Musa'ya zenginlikten korktuğunu, fakirliği tercih ettiğini ifade etmesi, Allah'ın ihsanıyla kulun kalan ömrünü de zenginlikle geçirmesi anlatılmıştır. "Kıyamette Ümmet-i Muhammed'in On Bölük Olduğu" başlığı altında yer alan hikâyede, Hz. Musa'nın ona inanmayan ve nefsine göre hareket eden arkadaşının domuz suretine sokulması anlatılmaktadır. "Tevekkül" başlığı altında yer alan hikâyede Hz. Musa ve Allah ile münâcâta giderken karşılaştığı mecusi arasında geçen konuşma ve daha sonra mecusinin imana gelmesi anlatılmıştır. "Sabır" başlığı altında Hz. Musa döneminde Firavun'un kızının dadısı Maşite'nin ve Firavun'un karısı Asiye'nin Allah yolunda şehit olmaları anlatılmıştır. "Evliyaların Dört Kısım Olduğu" başlığında Hz. Musa'nın Allah'ı kendi mekânına daveti, zaman ve mekândan münezzeh olan Allah'ın sevgili bir kulunu bu davete göndermesi, o fakir ihtiyara Musa ve çevresindekiler tarafından ehemmiyet verilmemesi, Allah'ın Musa'yı uyarması anlatılmıştır. Eserin "Teslim" başlı̆̆ı altında ise Hz. Musa ve Hızır kıssasına yer verilmiştir.

\footnotetext{
8 Eser hakkında bilgi için bk. Abdullah Uğur, Yazıcıŏglu Ahmed Bîcân Efendi ve Evâru'l-Âşıkin Adlı Eseri (İnceleme-Metin), Marmara Üniversitesi Türkiyat Araștırmaları Enstitüsü, Doktora Tezi, İstanbul, 2019. s. 316-344.

Abdullah Uçman, Müzekki'n-Nüfûs, İnsan Yayınları, İstanbul: 2019. s. 146-151; 206-208; 284-286; 309-315; 373-376;
} 549-552.

Adress

Kirklareli University, Faculty of Arts and Sciences, Department of Turkish Language and Literature, Kayalı Campus-Kırklareli/TURKEY e-mail: editor@rumelide.com 
Yukarıda zikrettiğimiz, belirli bir eserin içerisinde yer alan kıssa-i Musa metinlerinin yanı sıra manzum ve müstakil kıssa-i Musa metinleri de bulunmaktadır. Bunlardan birisi "Mûsâ-nâme10" adlı Mirza Ahmed bin Mirza Kerim tarafından Çağatay Türkçesiyle yazılmış, manzum eserdir. Bu eserde Allah'ın Hz. Musa ile konuşması manzum bir şekilde dile getirilmiştir. Manzum Kıssa-i Musa metinlerinin bir diğer örneği de "Kıssa-i Musa 'Aleyhi's-selâm Ma'a Fir'avn Kavmihi Min Ehli'l-Küfr ve'z-Zalam"11" adlı eserdir. Bu eserde, Hz. Musa'nın Firavun ile mücadeleleri ve Hz. Musa'nın Allah ile konuşması hadiseleri anlatılmaktadır.

$\mathrm{Bu}$ müstakil eserlerden bazıları da mensur kıssa-i Mûsâ metinleridir. Kütüphanelerde yaptığımız taramalarda ve elde edebildiğimiz metinler üzerine yaptığımız incelemelerde, kataloglarda kıssa-i Mûsâ, hikâyet-i Mûsâ, hikâye-i Mûsâ ismini taşıyan bu metinlerin Firavun'un tahta geçişiyle başlatılıp, Hz. Mûsâ'nın doğumu, peygamberliği, yaşadı̆̆ı sıkıntılar, Firavun'un helak edilişi, Hz. Musa'nın Allah ile konuşması, İsrailoğulları'nın Musa Tûr Dağı'nda iken bir buzağı heykeline tapınması, Hz. Mûsâ'nın üzüntüsü, kavmini imana davet etmesi hadiselerini işledikleri tespit edilmiştir. Rivayet şeklinde olan bu metinlerin çoğu tek bir metinden çıkmış izlenimi vermektedir. Bu metinler, çoğunlukla eksik ve başlıksızdır. Kataloglarda yer alan eser isimlerinin bazıları da konuya göre verilmiştir. Bu metinlerle beraber kütüphanelerde Münâcât-ı Mûsâ isimli metinler de tespit edilmiştir. Bu metinlerin içeriğini Mûsâ kıssasında yer alan Tûr Dağı'nda Mûsâ'nın Allah ile konuşması olayının ayrıntılı bir şekilde anlatımı oluşturmaktadır. Çalışmamızın konusu olan Kıssa-i Mûsâ'nın da konu itibariyle Hz. Musa'nın hayatı, peygamberliği ve mücadelelerini konu alan kıssa metinlerinden farklı olarak sadece Tûr Dağı'nda Mûsâ'nın Allah ile konuşması hadisesine dayandığı tespit edilmiştir. Besmele ile başlayan ve başlıksız olan bu metnin, konusuna göre isimlendirildiği kanaatine varılmıştır. Çalışmada da Münâcât-i Mûsâ metinleri doğrultusunda değerlendirmeler yapılacaktır.

\section{Kıssa-i Mûsâ (AS)}

\section{a. Kıssa-i Mûsâ (AS) metninin nüsha hususiyetleri}

Amasya Beyazıt İl Halk Kütüphanesi, o5 Ba 509/4 numarayla kayıtlı Kıssa-i Mûsâ (AS) metni, dini içerikli bir mecmuanın içerisinde yer almaktadır. Mecmuanın içerisinde öncelikli olarak Yahya b. Bahşi'nin Menâkıb-ı Emir Sultan adlı eseri, ardından sırasıyla Hasan Halvetî'nin Sülûki'l-'Âşıkîn ve İlâhiyat'ı son olarak da Kıssa-i Mûsâ metni bulunmaktadır. Metin, mecmuanın 146b-168b varakları arasında yer almaktadır. Harekeli nesih ile yazılmış olan metin, besmele ile başlamaktadır. Baştan veya sondan eksik olmayan metnin içerisinde müellifine dair bir bilgi bulunmamaktadır. Metnin sonunda müstensihe ait olduğunu düşündüğümüz şu ibarelere yer verilmiştir, metnin bu bölümünde vezin uyumsuzlukları dikkat çekmektedir:

"Bu kitābı yazanuñ ismi Kaya

Cümle mahlūḳuñ ḥāki olmuşdur gedā

Raḥmet aña kim du'ā eyle aña

Dahı cümle aḳrabasına ü hem aña

\footnotetext{
1o Eser hakkında geniş bilgi için bk. Deniz Ufuk Aşçı, Mûsâ-nâme (İnceleme- Transkrisiyonlu Metin-Çeviri-DizinTipkıbasım), Palet Yayınları, Konya, 2012.

Eser hakkında geniş bilgi için bk. Gökhan Ölker, Kıssa-i Musa 'Aleyhi's-selâm Ma'a Fir'avn Kavmihi Min Ehli'l-Küfr ve'zZalam, Palet Yayınları, Konya, 2013.
} 
Oḳuyanı yazanı diñleyeni

Raḥmetüñle yarlığgağl yā Ġani

Bu faḳirüñ ḥaḳḳına kim ‘aşḳ ile

Bir $d u^{(} \bar{a}^{\prime}-1$ ḩayr iderse șidḳ ile

Ḥaḳ Te`ālā raḥmet itsün anlara

Hem oḳuyub müstemi` olanlara

Cümlenüñ ḥaḳḳında söz bitdi hemīn raḥmet itgil yā İlāhe'l-`ālemīn."

Metnin istinsah kaydı da mevcut değildir.

Çalışmamıza konu olan "Kıssa-i Mûsâ" metninin, yaptığımız taramalar neticesinde Afyon Gedik Ahmet Paşa İl Halk Kütüphanesi'nde o3 Gedik 17166 numarada yer alan "Hâzâ Kitâb-1 Münâcât-ı Mûsâ 'Aleyhisselâm" adlı metnin muhtasar hali olduğu tespit edilmiştir. Bu metin, harekeli nesihle kaleme alınmış, mensur bir eserdir ve 60 varaktan oluşmakla beraber sondan eksiktir. Eserin son varağ okunduğunda kıssanın yarım kaldığı belirlenmiştir. Ayrıca metnin sonunda bir temmet kaydı da bulumamaktadır. Bununla beraber Afyon Gedik Ahmet Paşa İl Halk Kütüphanesi'nde bulunan bu metnin farklı eserler içerisinde yer alan üç ayrı nüshası da Milli Kütüphane'de o6 Mil Yz A 8651/1 (1b13b), o6 Mil Yz A 5849/3 (68b-94a), o6 Mil Yz A 1810/2 (3ob-5ob)'de yer almaktadır. Bu metinler de eserin sadece bir bölümünü kapsamaktadır. ${ }^{12}$

Bununla beraber kütüphanelerde Münâcât-ı Mûsâ (AS)13 adıyla kayıtlı olan başka metinler ise şunlardır:

Münâcât-ı Mûsâ, Milli Kütüphane Yazmalar Koleksiyonu, No: 06 Mil Yz A 3535/2.

Münâcât-ı Mûsâ, Afyon Gedik Ahmet Paşa İl Halk Kütüphanesi, No: 03 Gedik 17166

Münâcât-ı Mûsâ, Konya Bölge Yazma Eserler Kütüphanesi, 15 Hk 310/5

Münâcât-ı Mûsâ Aleyhisselâm, Süleymaniye Yazma Eser Kütüphanesi, Atıf Efendi Koleksiyonu oo189

Münâcât-ı Mûsâ, Süleymaniye Yazma Eser Kütüphanesi, Yazma Bağışlar 03564-003

Münâcât-ı Mûsâ, Süleymaniye Yazma Eser Kütüphanesi, Yazma Bağışlar 04056

Münâcât-ı Mûsâ, Süleymaniye Yazma Eser Kütüphanesi, Bağdatlı Vehbi Koleksiyonu 01578-002

\footnotetext{
12 Münâcât-i Mûsa başlıklı bir çalışmanın Ahmet Çaldıran tarafından yüksek lisans tezi olarak yapılmış olduğu tespit edilmiş olmasına rağmen metne ulaşılamadığı için metnin içeriği hakkında bilgi sahibi olunamamıștır. Çalıșma için bk. Ahmet Çaldıran, Münâcât-ı Musa Aleyhi's-Selâm (Metin-Çeviri-Dizin), Basılmamış Yüksek Lisans Tezi, Marmara Üniversitesi, Türkiyat Araştırmaları Enstitüsü, İstanbul, 1999.

13 Kütüphanelerde kayıtlı olan mensur Kıssa-i Mûsâ metinleri için bkz. Gökhan Ölker, Kıssa-i Musa 'Aleyhi's-selâm Ma'a Fir'avn Kavmihi Min Ehli'l-Küfr ve'z-Zalam, Palet Yayınları, Konya, 2013. s. 18; Hasan Sağlam, Kıssa-i Mûsâ (A. S.) (Söz Dizimi İncelemesi), Yüksek Lisans Tezi, Marmara Üniversitesi Türkiyat Araştırmaları Enstitüsü, 2019. s. 3. 
Münâcât-ı Mûsâ, Süleymaniye Yazma Eser Kütüphanesi, Fatih Koleksiyonu 04513-002 (Sağlam, 2019: 3)

Münâcât-ı Mûsâ (AS), Türk Dil Kurumu Kütüphanesi Türkçe Yazmaları, Yz. A 432/2.

Münâcât-ı Mûsâ Aleyhisselam, Konya Bölge Yazma Eserler Kütüphanesi, 42 Kon 278/5.

Zikredilen kütüphanelerin dışında dünya kütüphanelerinde kayıtlı olan Münâcât-ı Mûsâ (AS) metinlerine ait kayıtlar da şu şekildedir:

Münâcât-ı Mûsâ, Fransa Milli Kütüphanesi Türkçe Yazmaları, Colbert, 4546/Regius, 1291, 3.

Münâcât-ı Mûsâ, Fransa Milli Kütüphanesi Türkçe Yazmaları, Renaudot/Saint-Germain-des-Pres, 321.

Münâcât-ı Mûsâ (AS), Vatikan Türkçe Yazmaları Kütüphanesi, Barb. Orient. 52/5.

Münâcât-ı Mûsâ (AS), Gazi Hüsrev Kütüphanesi Türkçe Yazmaları, 2542/8.

Münâcât-ı Mûsâ (AS), Gazi Hüsrev Kütüphanesi Türkçe Yazmaları, R-621/1.

Münâcât-ı Mûsâ (AS), Gazi Hüsrev Kütüphanesi Türkçe Yazmaları, R-5523.

Münâcât-ı Mûsâ (AS), Gazi Hüsrev Kütüphanesi Türkçe Yazmaları, R-7396/1.

Münâcât-ı Mûsâ (AS), Gazi Hüsrev Kütüphanesi Türkçe Yazmaları, R-7679/1.

Münâcât-ı Mûsâ (AS), Gazi Hüsrev Kütüphanesi Türkçe Yazmaları, R-7948.

Münâcât-ı Mûsâ (AS), Gazi Hüsrev Kütüphanesi Türkçe Yazmaları, R-6728/1.

Münâcât-ı Mûsâ (AS), Gazi Hüsrev Kütüphanesi Türkçe Yazmaları, R-7742/2.

Münâcât-ı Mûsâ (AS), Dükalık Kütüphanesi Gotha Koleksiyonu Türkçe Yazmaları, arab. 1254, Seetzen Nr. $92 / 1$.

Münâcât-ı Mûsâ (AS), Hidiv Kütüphanesi Türkçe Yazmaları, 10207.

Münâcât-ı Mûsâ (AS), Mısır Milli Kütüphanesi Türkçe Yazmaları, Tasavvufı Türkî 133.

\section{b. Kıssa-i Mûsâ (AS) metninin dili ve muhtevası üzerine}

Kıssa-i Mûsâ metni, söz varlığı (dükeli, yarlıgamak, yavlak, sagu saglamak vb. kelimeler), ses ve şekil özellikleri dikkate alındığında Eski Anadolu Türkçesi dil özelliklerini taşıyan bir metindir. Aynı zamanda metinde, müstensihten kaynaklandığını düşündüğümüz imla ikilikleri söz konusudur. Örneğin, ki bağlacı bazen kim bazen ki olarak yazılmış, belirtme hali eki bazen [y] ünsüzüyle birlikte kullanılırken bazen hemze ile kullanılmıştır. Kelime sonlarındaki hemzeler ise bazı yerlerde kullanılmamıştır. "Hatā '" kelimesinde olduğu gibi. "Hูalḳ, hāṭı," kelimesi metnin çoğu yerinde "ḥ" harfi ile yazılmıştır. Çeviri yazıda doğru şekli olan "Ḩalk, hātır" biçiminde yazım tercih edilmiştir. 
Metinde diyalog üslubu kullanılmış bunun için de tekrarlara sıkça yer verilmiş, kısa cümleler ve anlaşılır ifadelerle birlikte okuyanın anlayabileceği sade nesir üslubu tercih edilmiştir. Metinde seslenme edatları ve ifadeleri (yâ İlahî, yâ Mûsâ gibi) sürekli tekrar edilmiştir. Bunun yanı sıra Arapça ayet ve dualara da yeri geldikçe yer verilmiştir. Metinde okuyanı eğitmeyi, doğru yola sevk etmeyi amaçlayan didaktik yön ağır basmaktadır.

"Kıssa-i Mûsâ" metni, muhtevası açısından incelendiğinde Musa kıssasının içerisinde bir bölüm olan Hz. Musa'nın Tûr Dağı'nda Allah ile konuşması ve Tevrat'ın indirilmesi hadisesinin metinde ayrıntılı bir şekilde işlendiği görülmektedir. Tûr Dağı, Musa Aleyhisselam'ın Allah ile konuştuğu ve Hakk'ın tecellisine mazhar olduğu yerdir. Envâru'l-Âşııin'de Hz. Musa'nın Tûr-ı Sînâ'ya kardeşi Harun'u yerine halife koyarak çıkması olayı şu şekilde ifadelendirilir: Şimdi bu işâretdür ki Mûsâ, Hak Te'âlâ ile mülâkât oldı telâkkî-i rûhânî ile. Andan sonra kelâm bedenine intikâl itdi. Ve nakildür ki Mûsâ münâcât itmek içün Tûr tagına çıkdı. Karındaşı Hârûn'ı yirine halîfe kodı (Uğur, 2019: 326). Hz. Musa'nın münâcât etmek için Tûr Dağı'na çıkması ifadesi dikkate alındığında Musa kıssasında bu konuyu işleyen bölümlere Münâcât-ı Mûsâ başlığı verilmesinin konu ile paralel olacak bir şekilde gerçekleştiği görülmektedir. Edebiyat terimi olarak Allah'a yalvarma, yakarma, niyazda bulunma ve dua etme maksadıyla kaleme alınan manzumeler şeklinde tanımlanan münâcâtlar, klasik edebiyatta sadece manzum olarak değil mensur olarak da kaleme alınmıştır. Mensur münâcâtların en güzel örneği XV. yüzyılda Sinan Paşa tarafından kaleme alınan "Tazarru'-nâme" adlı eserdir. Agah Sırrı Levend, dinî edebiyatımızının başlıca ürünleri içerisinde münâcâtları işlerken klasik edebiyatta "münâcât-nâme" ve "tazarru'-nâme" adlarını taşıyan mensur eserlere dikkat çekmiştir. "Bunların arasında en önemlisi XV. yüzyll yazarlarından Maazoğlu Yahya'nın Münacat-name'siyle, Sinan Paşa (Ö. H. 891=M. 1486)'nın Tazarru'-name'si ve Ali Şir Nevaî (Ö. H. 907=M. 1051)'in Münacat-name'sidir (2016: 401)." Canım, münâcâtlar için şu ifadeleri zikretmektedir: "Münâcâtlarda yer alan duygular belirgin ve müşterek olmasına rağmen şairlerin mizac, meşrep ve tahsil durumlarından kaynaklanan çeşitlilik de göze çarpar. Ayrıca münâcâtları dinî ve tasavvufî esaslara göre yazılanlar diye iki kısıma ayırmak mümkündür. Dinî örneklere dönemin medrese kültürünün yansıdığı ve zaman zaman tefekkürün hikmete dönüştüğü, bazen bunların didaktik bir hâl aldığı görülür. Tekke-tasavvuf erbabının münâcâtalarında ise daha coşkulu bir ruh halinin sonsuzluğa kanat açışını sezmek mümkündür (2012: 169)." Bu dikkatle "Kıssa-i Mûsâ" metnine bakıldığında metnin okuyanı eğitmek, okuyanlara bazı dinî hususları, edebî eserlerin etkileyiciliğinden de faydalanılarak öğretmek maksadıyla kaleme alındığını ifade etmek yerinde olur. Kıssa-i Mûsâ metninde işlenen konular ve metnin özeti şu şekildedir:

Hz. Musa Allah'ın davetiyle Tûr Dağı'na çıar. Burada başlangıcta Cebrail ve meleklerle karşılanan Hz. Musa, Allah'ın kelamına mazhar olur. Âlemlerin yaratıcısı olduğunu dile getiren Allah Teâlâ ilk olarak kâinatı, geceyi-gündüzü, güneşi-ayı, bütün pegamberleri yaratma sebebi olarak Hz. Muhammed'i gösterir ve Hz. Musa'nın ona çok salavat getirmesini ister. Hz. Musa ise Hz. Muhammed'in üstünlüklerini sorar. Kendisinin mi Hz. Muhammed'in mi daha sevgili olduğunu öğrenmek ister. Allah, Hz. Musa'nın kelimullah olduğunu Hz. Muhammed'in ise habibullah olduğunu söyler ve O'na Musa'nın Tûr'da Muhammed'in arşta münâcât ettiğini ifade eder. Sonra Muhammed ümmetinin üstünlüklerini sıralar. Muhammed ümmetinin üstünlükleri; abdest, beş vakit namaz, Ramazan, zekat, hac, aşure, riyaz$ı$ cennet, mescid yapmak olarak sıralanır. Metnin giriş bölümü ve münâcâtın başlangıcı olan bu bölümde Hz. Muhammed ve onun ümmetinin faziletleri, ona ve onun getirdiklerine iman etmenin gerekliliği, ona iman etmeyenlerin durumu, Hz. Muhammed'in şefaatçiliği, cennet kapılarının Hz. Muhammed ümetiyle açılacağı ayrıntılı bir şekilde anlatılır ve akabinde Hz. Muhammed ümmetinin ibadetleri ve sevaplarına değinilir. Beş vakit namaz, Ramazan orucu, Kadir gecesi, eyyamü'l-beyz orucu ve bu ibadetlerin faziletleri tek tek açıklanır. Halkların en üstünü ve yaramazı hakkında da bilgi verilir. 
Halkların en üstünü Allah'ı hiçbir vakit unutmayan ve günahları için tövbe eden; halkların en yaramazı da aşikârda ibadet edip gizlice günah işleyenler olarak tanıtılır. Daha sonra Hz. Musa'ya hangi hasletleri taşıması gerektiğine dair uyarılarda bulunulur ve bunları yapacakların dünya ve ahirette kazançlarına değinilir. Bu hasletlerle beraber cehennem tasviri yapılarak yapılan uyarılara, insanların uymaları istenir. Bu hasletler şunlardır:

1. Yoksullara müşfik davranma ve onlardan yardımı esirgememe

2. Dullara şefkatli olma

3. Miskinleri esirgeme

4. Verilen nimetlere şükretme

5. Cömert olma

6. Zenginlere ve fakirlere eşit davranma

7. Giybet ve koğuculuk yapmama, ayıbı olanın ayıbını örtme

8. Kendi nefsi için istediğini başkaları için de isteme

9. İyilikte de kötülükte de sözü bir olma

10. Nerede olursa olsun ilmi arama ve ilimle amel etme, âlimlerin meclisinde bulunma ve onlarla sohbet etme

11. Öfkesine yenik düşmeme, firsatı olduğunda suçluyu affetme, başkalarının yaptıklarına karşı sabır ve tahammül gösterme, kimseyi incitici laflar etmeme, eli altında çalışanlara hoşgörülü davranma, gazaptan uzak durma

12. Şükür ve kanaat sahibi olma, elindekini başkalarıyla paylaşma, kapısına geleni boş çevirmeme

13. Helal kazanma ve bir mümin kardeşinin hacetini gidermesine yardımcı olma, başkalarının malına tamah etmeme, faizden uzak durma

14. Allah'tan korkmayı ve Allah'tan utanmayı bilme

15. Kötüye karşı iyi olmayı, yapılan kötülüğe karşı iyilik yapmayı bilme

16. Allah'a her daim kulluk etme ve şirkten uzak durma, her an Allah'ı zikretme, Allah'ın farzlarını yerine getirme, zekât verme, Allah rızası için sadaka verme

17. Başkalarından methüsena ummama

18. Gösteriş için ibadet yapmama, ibadeti gizli yapma

19. Anneye, babaya saygı gösterme ve onlara itaat etme 
19. Sözünde durma ve emanete hıyanetlik etmeme, yalan yere yemin etmeme, yalan söylememe

20. Misafire hürmet gösterme

21. Ölümü her an anma ve onu akıldan çıkarmama ve nefsinin arzularından uzak durma

22. Başına gelen felaketlere rıza gösterme, onlardan şikâyetçi olmama

23. Dünya varllğından vaz geçip yoksulluğu tercih etme, düyayı hor görme

Allah'in kulunda bulunması gereken hasletleri anlatmasından sonra sira Musa'ya gelir ve Musa Allah'in nerede bulunduğuna, evreni yaratışına, meleklere, ezel ve ebede dair bilgi almak için sorular sorar ve gerekli cevapları alır. Metnin sonunda evrenin yaratılışına ve Allah'ın ezelî ve ebedî oluşuna dair ayrıntılı bilgiler verilir. Hz. Musa'ya Hak katında yapılması iyi olan hasletler, kaçınılması gereken davranışlar bildirilir ve Musa ile vedalaşllır. İçerik olarak değerlendirildiğinde bir münâcât-nâme olarak değerlendirebileceğimiz bu metin hem Hz. Musa'nın Allah'a yakarışını konu almakta hem de metinde bir müminin taşıması gereken hasletler net ve didaktik bir üslupla dile getirilmektedir.

\section{Sonuç}

1. Kur'an kıssaları, klasik Türk edebiyatının temel kaynaklarından birisidir. Kur'an kıssalarının büyük bir çoğunluğunu oluşturan peygamber kıssaları da manzum ve mensur pek çok eserin kaynağı olmuş, bu kıssalar hem manzum metinlerin içerisinde bir telmih ve teşbih unsuru olarak metnin anlam dünyasını zenginleştirmiş hem de müstakil eserlere konu olmuştur. Kur'an'da en çok zikredilen Hz. Musa kıssası da bunlardan birisidir. Özellikle Tûr Dağı'nda yaşadıkları ve Allah'ın tecellisine mazhar olması, asasının yılana dönüşmesi, Firavun ile mücadelesi, Firavun ve askerlerinin denizde boğularak helak olması, Hızır olarak isimlendirilen bilge kul ile yaşadıkları, yed-i beyza mucizesi ile edebi metinlerin içerisinde sıkça kullanılmıştır. Kısas-ı enbiyalarda, dinî-tasavvufî, didaktik metinlerin içerisinde veya müstakil manzum ve mensur metin olarak klasik edebiyatta sıkça kullanılan Hz. Musa kıssasının, bazen Hz. Musa'nın doğumundan vefatına kadar yaşadıklarının tümü bazen de bir bölümü bu metinlere kaynaklık etmiştir.

2. Kıssa-i Mûsâ metinleri üzerine yapılmış çalışmalar incelendiğinde ve kütüphanelerde yapılan taramalar dikkate alındığında Kıssa-i Mûsâ metinlerinin;

a. Kısas-ı enbiyalara da konu olan Hz. Musa'nın doğumundan vefatına kadar yaşadıklarını konu alan anlatılar

b. Kıssanın içerisinde yer alan Hz. Musa'nın Tûr Dağı'nda Allah ile konuşmasını konu alan münâcât-ı Mûsâ olarak da isimlendirilen anlatılar

c. Hz. Musa'nın Firavun'la mücadelesini konu alan anlatılar

d. Hz. Musa ve Hızır konusunu ele alan anlatılar

şeklinde maddelendirilerek değerlendirilmesi yerinde olacaktır. Zira yapılan incelemeler neticesinde başlığı farklı olsa da içeriği aynı olan kıssa-i Mûsâ metinleri karşımıza çıkmaktadır. Bu da bu metinlerin 
tarih boyunca çokça beğenilmiş ve halkın zihninde yer edinmiş olduğu ve bu doğrultuda çeşitli eserlerin içerisinde veya müstakil olarak sık sık tekrar edildiği gerçeğini bizlere göstermektedir.

3. Kıssaların önemli bir özelliği peygamberlerin hayatı vasıtasıyla okuyucuyu bilgilendirmek, okuyucunun okudukları vasıtasıyla kendisini değerlendirmesine vasıta olmaktır. Kıssa-i Mûsâ metni içerik olarak değerlendirildiğinde müminlerin yapıp yapmaması gerekenler hususunda net bilgiler içeren bir metin olarak karşımıza çıkmaktadır. Öyle ki karşılıklı konuşma şeklinde ilerleyen metinde Allah'ın kullarında bulunmasını istediği ve istemediği iyi ve kötü özellikler sıralanmış, insanın bu anlatılanlardan kendisine ders çıkarmasına yönelik bir üslup takip edilmiştir.

4. Çalışmada Amasya Beyazıt İl Halk Kütüphanesi, o5 Ba 509/4 numarayla kayıtlı Kıssa-i Mûsâ (AS) metni temel alınmış, metnin transkripsiyonlu metni verilmiştir. Metin dinî içerikli bir mecmuanın içerisinde yer almaktadır. Özellikle kütüphanelerdeki münâcât-ı Mûsâ metinleri tarandığında ve elde edilebilen nüshalar gözden geçirildiğinde içerik ve dil özellikleri bakımından bu metinlerin birbirine benzediği tespit edilmiş; fakat metinlerin çoğunun baştan veya sondan eksik olduğu, elimizdeki metnin ise muhtasar bir nüsha olduğu belirlenmiştir. $\mathrm{Bu}$ da metnin içeriği hakkında genel bir bilgi edinebilmemiz açısından önemli bir unsur olmuştur.

\section{KISSA-İ MÛSÂ METNİ}

[146b] Bismillaḥirraḥmānirrahịm

Ka'bü'l-aḥbār raḍiyallāhu 'anhu rivāyet ider Mūsā Peyġamber'den ('AM). Kaçan kim Tañrı Te'ālā Mūsā peyġambere emr eyledi kim yā Mūsā Ṭūr Ṭag̀ı'na çık. Mūsā daḩı Tañrı emriyle Ṭūr Ṭag̀ı'na çıḳdı. Cebrā iìl 'Aleyhisselām feriştehlerle ḳarşu geldi. Ṭūr Ṭag̀ı'nda ne ḳadar cān-vārlar var ise dükelisin șürdiler. Çün Mūsā 'Aleyhisselām anı gördi bildi kim Ḥaḳ Te' ālā anuñla söyleşmek diler. Mūsā'nuñ dahı başında bir ḳara dülbendi ve 'abadan cübbesi ve 'abadan serāvīili ve keçeden bürgi ve elinde ' asāsı var idi. Țūr Ṭaǵı'nuñ üstünde ol ḳadar ferişteh inmişdi kim yeryüzinde ne kim var ise dükelisi örtülmişdi. Andan Cebrā 'ìl ' Aleyhisselām Mūsā'ya eyitdi kim yā Mūsā dülbendün etegüñ ile yüzüñ ve alnuñ ört. Mūsā dahı dülbendi etegiyle yüzün ve alnın ör-[147a]-tdi. Şöyle kim iki gözünden gayri nesnesi görünmezdi. Tā kim Tañrı Tebāreke ve Tecālā'nuñ kelām-ı nūrından göyünmeyeydi. Andan Mūsā peyġamber ('AM) Ḥaḳ Te`ālā kelāmına yavlaḳ urdı. İşitdi kim Ḥaḳ Tebāreke ve Te`ālā eyitdi: Yā Mūsā ben ol Tañrı'yam kim cemí ' -i 'ālemleri yaratdum. Benden artuḳ Tañrı yoḳ. İmdi yā Mūsā sen dahı baña ḳulluḳ eylegil ve benüm emrüm dutğııl. Mūsā daḩı eyitdi: Beli yā Rab sen ol Tañrı'sın kim senden artuḳ Tañrı yoḳ ve dükeli maḥlūḳāta sen rızḳ virürsin ve ben daḩı senüñ ḳuluñum. Senden gayri kimsem yoḳ. Ḥaḳ Tebāreke ve Te`ālā eyitdi: Yā Mūsā eger ḳullarumdan beni yād ider ve baña yüz dutar kişiler olmayaydı ḳullarumdan kendözümi ıraḳ dutaydım. Yā Mūsā, eger ḳullarumda "Lā-ilāhe illa'llāh" dir kişiler olmayaydı gökden yire bir ḳatre yag̉mur endürmeyeydüm ve yerde bir yabraḳ bitürmeyeydüm. Yā Mūsā eger ḳullarum olmayaydı țamuduñ ḳaynar șu-[147b]-ların dünyāya seyl gibi aḳıdaydım. Eger ḳullarumda baña ḥamd idüb ve beni birgici ḳullarım olmayaydı halḳlaruma göz açub yumınca mühlet virmeyeydüm. Yā Mūsā, benüm ḩoşnūdlug̉um ve baña dahı̆ yaḳın olmag̉a diler misin? Ḥattā sözüñ dilüñe ne deñlü yaḳın ise sen dahı baña ol deñlü yaḳın ol. Mūsā eyitdi: Beli yā Rab benüm dahı dilegüm oldur. Ḥaḳ Te ālā eyitdi: Yā Mūsā, Muhammed üzerine çok șalavāt getür ḳaçan kim Mūsā Muhammed adın işitdi Tevrit'í elinden bıraḳtı. Tevrìt țoḳuz levḥ idi. Üç levḥ göge uçdı, altı yirde ḳaldı. Muḥammed gaayretinden Ḥaḳ Te` ālā eyitdi: Yã Mūsā, saña ne virdümse al bunā daḩı şükr eyle. Mūsā elin șundı alt[1] levḥ̣ yirden götürdi. Andan Mūsā ('AM) Ḥaḳ Te`ālā'ya eyitdi: Yā İlāhī, Muḥammed ki bir kişi saña yaḳın olmaz illā Muḥammed'e șalavāt getürmekle yaḳın olur. Ḥaḳ Te âlā eyitdi: Yā Mūsā Muḥammed ol kişidür ki [148a] eger Muhammed olmayaydı yerler ü gökler olmayaydı. Ay ve güneş ve gece[y]i ve gündüzi yaratmayaydum ve dahı muḳarreb feriştehler ve mürsel peyġamberleri ve seni dahı yaratmayaydum ve dahı yā Mūsā eger Muḥammed'üñ peyġamberligina iḳrār eylemazsañ ve dahı aña șalavāt getürmezseñ seni oda yaḳaram eger İbrāhim Ḥalīi olacaḳ olursañ dahı. Andan Mūsā eyitdi: Yã ilāhī, Muhammed'e iḳrār getürdüm ve țanuḳluḳ 
virdüm ki Muhammed ḥaḳ peyġāmberdür dükeli ḩalḳdan efḍaldur ve dahı Mūsā Muḥammed'e çoḳ ṣalavāt getürdi. Andan Mūsā eyitdi: İlāhỉ senüñ ḳatuñda ben mi sevgülüyem yoḩsa Muḥammed mi? Ḥaḳ Tecāāā eyitdi: Yā Mūsā, sen kelïmümsin, Muḥammed ḥabỉbümdür. Ḥabỉbüm kelīmden sevgülüdür ve dahı yā Mūsā, sen benümle Ṭūr'da münācāt idersin Muḥammed benümle `arş üzerinde münācāt ider. Mūsā eyitdi: Yā İlāhî̉, senüñ ḳatunda Benì İsrā ’ìl sevgülüdür ya Muhammed ümmeti mi? [148b] Ḥaḳ Te`ālā eytidi: Yā Mūsā, Muḥammed ümmeti benüm ḳatumda Beni İsrāil'den sevgilidür. Mūsā eyitdi: Muḥammed senüñ ḳatunda ne kerāmet ile ḥürmetlüdür. Ḥak Tec ālā eyitdi: On dürlü kerāmet ile. Mūsā eyitdi: Ol kerāmetlerden nedür? Ḥaḳ Te`ālā eyitdi: Yā Mūsāà, ? evvel kerāmetle ikinci ābdest kerāmet ile üçünci beş vaḳt namāz kerāmetiyledür. Dördünci zekāt kerāmetiyle beşinci Ramażān kerāmetiyle altıncı hac kerāmetiyle yedinci ' aşūre kerāmetiyle țokuzuncı riyāz-1 cennet kerāmetiyle onuncı mescid yapmaḳ kerāmetiyle. Mūsā eyitdi: Yā İlāhỉ, riyāż-1 cennet ne nesnedür? Ḥaḳ Te` ālā eyitdi: Yā Mūsā, riyāz-1 cennet meclis-i 'ilmdür. Ya' ní uçmaḳ bag̣çeleri dimek, olur. Mūsā eyitdi: İlāhî, ol 'ilm meclisinde ne zikiri iderler ve benüm ' azāābumdan ḩışmumdan ḳullarumı ḳorḳudurlar. Girü ḳalan ḩalḳ ol ' ilm içinde otururlar ol 'ālimlerüñ va' iẓ nașiḥatin diñlerler ve dahı yā Mūsā, anlar ol 'ilim meclisinden țurub gitdikleri [149a] vaḳtin cemí' 'i günāhları yarlıganub giderler günāhları țag̉lar gibi daḩı olursa dahı. Yā Mūsā, sen Muḥammed'i sevgil. Nitekim kendü nefsiñi seversin ve anuñ ümmetine haber deyilgil. Nitekim Beni İsrā 'îl içün dilersin eger eyle itmezseñ dükeli ' amellerüñi hebā'-i Mașūr eyleyem. Yā Mūsā, ḳyāmet gününde dükeli ḩalḳ, nefsenī nefseni diye; ammā Muḥammed, ümmeti ümmeti diye. Yā Mūsā, İsrā 'ìl'e eyitgil her kim Muhammed'üñ peyġāmberlig̣ine inanmazsa țamu zebānīlerin ol kişinün üzerine musallaț eyleyem. Benüm ile ol kişi arasında bir ḥicāb eyleyem. Ḳıyāmet gününde ol kişi seni dahı görmeye ve hiçbir peygamber ol kişiye şefā' at itmeye. Yā Mūsā, Bení İsrāàìl'[e] eyit her kim ki Muhammed'[e] imān getürse ve anuñ peyġāmberlig̀ını tașdịk itse ve ümmetine hayr șansa baña vācibdür kim ben ol kişiyi yarlıgaayam ve ol benüm ḳatumda dükeli ḩalḳdan hürmetlü ola ve sevgilü ola. Yā Mūsā, her [149b] Muhammed kitābınuñ kelāmına bir ḥarfine inanmasa ben ol kişi[y]i ḳıāmet gününde oda yaḳaram. Yā Mūsā, Beni İsrā 'ìl'e eyit kim her kim baña inana ve Muhammed'e inana ve ḥayrı şerri benden bile ben ol kişiye țamu odından berü yazam ve 'azāāımdan emīn ḳ̂lam. Yā Mūsā, Beni İsrā'î̀l'e eyitgil her kim Muhammed'üñ şerī' atine inana ve anuñ sünnetin duta ol ḳula ölüm ḳatılıg̀ı olmaya ve ol kişinüñ cānı enbiyālar cānı gibi ola ve ol kişinüñ sini ḳyāmet gününde uçmak bag̣çelerinden bir bag̣çe ola. Ol kişi Münkir ve Nekỉr suvālinden āmīin ola ve ḳabr 'azāābundan āmin ola. Yā Mūsā, Muhammed nūridür. İmān getürenlere şefí‘ dür. Günāhlar ne ḳıyāmet gününde ve dahı anuñ ümmeti dünyā ümmetlerinüñ āhiridür. Yā Mūsā, uçmak peygaāmberlere harāmdur tā Muhammed ümmetiyle girmeyince. Yā Mūsā, İbrāhīm oğlı İsmācil'den ḳaça ve sen ve sen ḳarındaşuñ Hārūn'dan ḳaçasın; ammā Muhammed, ümmetinden ḳaçmaya anlara şefāe at ide. Anları țamu odından ḳurtara. Yā Mūsāa Muhammed ümetinüñ bir 'ameline [150a] on șevāb virem ve yetmiş günāhlarına bir cezā idem. Mūsā eyitdi: Yā İlāhí, Muḥammed ümmetine dürlü tậa at buyurduñ. Baña dahı bildürgil. Tā ki ben daḩı Beni İsrāàil'e buyuram, işleyeler. Ḥak Te $e^{c} a$ āa eyitdi: Anlara iki rek at erte namāzın buyuram. Her rek atiyçün aḩşamdan șabāḥa degin țậa at idene sevāb virülürse aña dahı ol șevāb virem ve dahı dört rek ${ }^{`}$ at öyle namāzın buyurdum. Evvel rek at içün mag̉firetüm rūzi ḳıldum. İkinci rek' at içün ḩoşnūdlug̉um rūzi ḳıldum. Üçünci rek' at içün ḳıyāmet gününde terāzūde șevābı ag̉ır ḳılam. Dördüncüde rek$^{`}$ atçün uçmaḳ ḳapuların ol kişiye açam ḳang̀ dahı dört rek' at ikindü namāzın buyurdum. Her rek' atiyçün bir yıl oruc dutmuş șevāb[1] virem ve dahı yā Mūsā, gök feriştehleri ol kişinüñ yarlıg̉anmasın dilerler ve dahı üç rek ${ }^{`}$ at ahşşam namāzın buyurdum. Her rek ${ }^{c}$ atiyçün yek yıllıḳ günāhların yuyam ve dahı dört rek' at yatsu namāzın buyurdum. [150b] Her rek' atiyçün Mescidü'l-ḥarām içinde bir yıl oruc ve bir yıl ' ibādet ḳılmış șevāb[1] virem. Yā Mūsā, Muhammed ümmetine Kadir Gicesi'ni virdüm. Ramażān ayı içindedür. Ol gicede altı yüz biñ kez yüz biñ günāhlu ḳullarumı țamu odından āzād iderem. Yā Mūsā, eger Muḥammed ümmeti Muharrem evvelinde on günin oruc dutsalar her günine bir yıl oruc dutub ve bir kul azād itmek șevābın virem ve dahı Muhammed ümmetiden Ramażān ayın oruc dutalar uçmak içinde ol nesneleri virdüm ki gözler gördigi yoḳ. Yā Mūsā, oruc dutanlaruñ ag̉zı ḳokusı benüm ḳatumda misk ü ‘ anber ḳokusından yigrekdür. Yā Mūsā, uçmaḳuñ bir ḳapusı vardur adı reyyāndur. Ol ḳapudan kimse girmez. İllā oruc dutanlar girer ve dahı yā Mūsā, ḳyāmet gününde ol kişinüñ dīiānında çok istig̀fār ola. Yā Mūsā eger Muhammed ümmeti eyyāmu'l-beyż orucun dutsalar anlaruñ köşklerin uçmaḳ üzerinde ḳılam. Ķıāmet gününde yüzleri ayuñ on dört gicesi [gibi] rūşen ola. Mūsā eyitdi: İlāhi, eyyāmü'l-beyż günleri ben kuluna bildür. Ben daḩı Beni İsā 'ìl'e bildürem. Ḥak Te $\mathrm{Ca}^{\mathrm{a}} \mathrm{lā}$ eyitdi: Her ayuñ on üçünci on dördünci ve on beşinci güni eyyāmü'l-beyż günleridür. Yā Mūsā, her kim dünle halḳ

Adress

Kirklareli University, Faculty of Arts and Sciences, Department of Turkish Language and Literature, Kayalı Campus-Kırklareli/TURKEY e-mail: editor@rumelide.com 
yatduġı țurub dün namāzın ḳılsa ve dahı benüm ḩoşnūdlug̉um mağfiretüm dilese ben ol kişiden utanuram ḳıyāmet gününde ' azāāb itmege. Eger ol kişinüñ günāhı yirler ve gökler ag̉ırınca olursa. Yā Mūsā, her kim nefsini acıḳdursa ve suṣatsa benüm uçmag̉umdaġı ni` metlerüm ve şerbetlerüm țalebi içün ben dahı ol kişiye hoşnūdlugium rūzi ḳılam ve belālarumi ol kişinüñ üzerinden șavam. Yā Mūsā, ḳang̀ı ḳulum beni sevse ol baña āṣi olmaz. Kanğı ḳulum ki benden utana ādem oglanınuñ ḳatında işlemedügi nesne[y]i benüm ḳatumda daḩı işlemaz. Zīiā her yerde beni ḥāżır görür, benden utanur. Yā Mūsā halḳlaruñ yegregi anlardur ki beni unutmayalar ve günāhlarından ötürü tevbe [151b] ḳılalar ve dahı yā Mūsā, halḳlaruñ yaramazı anlardur ki āḩiret 'ameliyle dünyā țaleb ider. Hูalk ögünde baña țâ‘ at iderler ve ḥalvetde ma' șiyet işlerler. Yā Mūsā, öksüzlere müşfik ata gibi olg̀ıll. Anlara müdām şefḳat eylegil. Tā ben dahı̆ saña şefḳat eyleyem ve dahı yā Mūsā dullara şefkatlü er gibi olg̀ıl. Gariiblere sevgülü ḳardaş gibi ol, ben daḩı anı severem. Yā Mūsā miskinleri esirgegil anlara yüz göstergil ki ḳyāmet gününde günāhlular șafunda ḳoymayasın. Yā Mūsā yoḩsullardan vergi dirìg itme tā ki ben daḩı senden ni` meti dirìg itmeyem. Yā Mūsā virdügüm ni` metlere şükr eyle kim ziyāde ḳllam. Hem dünyāda ve hem āhiretde yā Mūsā sen kerīm ol. Tā ben daḩ saña keremler gösterem. Yā Mūsā, ol Müslümān ki bahỉl ola, țamu içinde temeyyüz ide, cömerd kāfirler 'azābına. Yā Mūsā, benüm hulḳum gibi hulḳ eylegil. Zïrā her kim benüm hulḳum gibi hulk eylese ben utanuram ol kişiye ḳıyāmet gününde 'azāāb itmege eger kāfir dahı olursa. [152a] Yā Mūsā, bāyları nice ag̉ırlarsan yokssulları dahı eyle ag̉ırla ve illā ben didigüm gibi itmeyecek olursañ cemi' $-\mathrm{i}$ ' amellerüñi yuyam ve günāhlaruñı țağlar gibi eyleyem. Yā Mūsā, eger yoḳsullar bāylaruñ șadaḳaların almayalardı yire emr ideydüm dükeli bāyları yudaydı ve yoḳsulları ḳoyaydı. Yā Mūsā, miskinlere dāyim șoḥbet eyle zirā kim raḥmetüm miskinlerden göz açub yumuşca ıraḳ olmaz. Andan Mūsā ('AM) 'ādet idindi. Her bir ayda miskinleri țavāf iderdi. Eger hāacetleri var ise ḥācetlerin revā ḳ̂lurdı, ac ise tọururd. Andan Ḥaḳ Te āli'den nidā geldi kim yā Mūsā senden hoşnūd oldum ve dükeli yarlıgadum ve dahı yā Mūsā her kim miskinleri țavāf itse anlaruñ dahı cemíc -i günāhların yarlığayam. Andan Mūsā ('AM) yigirmi ḳaravaş aldı ki miskinlerüñ ḳaftanın ve göñleyin yumag̉a ve anlara hııdmet itmege andan Te` ālā eyitdi: Yā Mūsā, her nice kim sen idersin `ivāżı̀n bulasın. Her ne kim istersen ala getüre- [152b] -sin. Mūsā ('AM) eyitdi: İlāhī ‘ arş altında bir kişi gördüm ag̉zından kāfir-i misk gibi rāyiḥālar ḳokar. Ol ḳang̀ı peyġāmberdür Hुak Te`ālā eyitdi: Yā Mūsā, ol kişi şol kimsedür kim ‘ ömri içinde kimsenüñ ġ̀ybetin söylemedi, ḳoculuk itmedi. Ol sebebden ol kişi ol mertebe’i buldı. Mūsā, İlāhỉ senüñ ḳatuñda ḳang̀ı kişi sevgülüdür? Ḥaḳ Te ālā eyitdi: Yā Mūsā, benüm ḳatumda şol kimesne sevgülüdür ki kendü nefsi içün ne șanursa ġayriye dahı eyle șana. Mūsā (' $\mathrm{AM}$ ) eyitdi: İlāhỉ senüñ ḳatuñda ḳanġı ḳuluñ ‘ālimdür? Ḥaḳ Te`ālā eyitdi: Yā Mūsā, ol şu kimsedür ki gurbete düşüb halḳdan 'ilim ögrenmege gide. Ḥaḳ Te' ālā eyitdi: Yã Mūsā demürden carık eylegil ve tucdan 'așā eyleyüb dahı ' ilm isteyü varğıl. Tā şol vaḳte degin carugunun eskiye ve 'așāñ uvana. Zỉrā yā Mūsā, ' ilim ' amelüñ ḳulavuzdur ve dahı yā Mūsā ' ilimsiz ' ammāl girüşiz ziyāya beñzer ve 'amelsüz 'ilim yemişsiz ag̉aca [153a] beñzer ve zekātsuz ' ilim ve 'amel yag̉mursuz ra' da beñzer ve daḩı yā Mūsā ḥarām māldan zekāt virmek ve ḥarām māl ile ' ilim taḥ̣ịl itmek şuña beñzer ki incüyi ve yāḳūtı hıızire veya kelb boynına aṣmak gibidür ve ḥelāl māldan zekāt virüb ve yalan söylemek ve ġybet ve ḳoculuk itmek şu ki beñzer ki ol virdigi zekāt sinleler üzerine varub sacu sacmak gibidür. Zīrā ol ululara ol șaçudan fāyide yoḳ aña dahı ol virdügi zekātdan fāyide yoḳ. Mūsā eyitdi: İlāhỉ halḳuñ düşmānı oldur kim halḳuñ ardınca gaybetin söyler ve halḳı ve 'ayb ola kendü işler. Mūsā eyitdi: İlāhỉ ḳullaruñda ḳanġı ḳuluñ gerçek söyler? Ḥaḳ Te ālā eyitdi: Yā Mūsā ol ḳulumdur ki hoşluḳda ve nā-ḩoşluḳda sözi bir ola. Mūsā eyitdi: İlāhi ḳullaruñda ḳang̀ k kuluñ cömerd ola? Ḥaḳ Te ālā eyitdi: Yā Mūsā ol miskinlerden ța āmın dirìg itmeyen

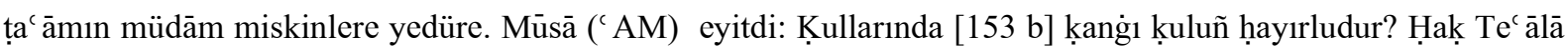
eyitdi: Ol kişidür ki gażab vaḳtinde yavaş ola ve gayrì kişinüñ ve yoldaşınuñ cezāsına ḳatlana. Mūsā eyitdi: İlāhī, ḳullaruñda ḳanġı ḳuluñ ‘ ācizdür? Ḥaḳ Te`ālā eyitdi: Ol kişidür ki ' amālsuz uçmaḳ iste ve du' āsuz belāyı șavmaḳ iste. Mūsā eyitdi: İlāhí, ḳullaruñda ḳanġı ḳuluñ bahỉldür? Ḥaḳ Te ālā eyitdi: Ol kişidür ki evinde nesne var iken dervişi mahrūm göndere ve dahı mü'min ḳardaşlar göre selām virmeye. Mūsā eyitdi: İlāhi kụullaruñdan ḳang̀ k kuluñ bāydur? Ḥaḳ Te ālā eyitdi: Ol kişidür ki bugünüñ ḳutuna ḳana' at ide. Yarın içün yoḳdur diyü gușșa yemeye. Mūsā eyitdi: İlāhi ḳullaruñda ḳang̀ı ḳuluñ şaḳidür? Ḥaḳ Te`āāā eyitdi: Ol kişidür ki günāh işler ve günāhına tevbe ḳılmaz. Mūsā eyitdi: İlāhî, [154a] ḩalḳlaruñ yigregi kimdür? Ḥaḳ Te ālā eyitdi: O kişidür ki rıżìi ḥelālden ola ve bol ola ve mü’min ḳarındaşınuñ ḥācetin bitüre. Mūsā 'Aleyhisselām eyitdi: İlāhỉ ḳullaruñda ḳang̀ı ḳuluñ zạalimdür? Ḥak $\mathrm{Te}^{c}$ àlā eyitdi: Ol kişidür ki ne benden ḳorka[r] ve ne utanur. Mūsā eyitdi: ḳullaruñda ḳang̀ı ḳuluñ cömerddür? Ḥaḳ

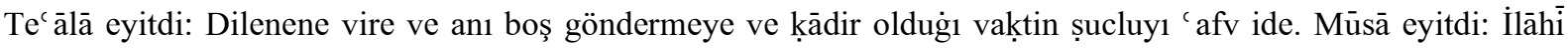

Adress

Kirklareli University, Faculty of Arts and Sciences, Department of Turkish Language and Literature, Kayalı Campus-Kırklareli/TURKEY e-mail: editor@rumelide.com 
kullaruñda ḳanġı ḳuluñ isrāfdur? Ḥaḳ Tecālā eyitdi: Ol kişidür ki yedügin ve içdügin bilmeye helāl midür veyā ḥarām mıdur. Mūsā eyitdi: İlāhî, ḳanġı ḳuluñ çirkindür? Ḥaḳ Te` ālā eyitdi: Ol kişidür ki bir kişinüñ ' aybını halḳa fāş ider ve 'ayb olanı kendü işler. Ḥaḳ Te ālā eyitdi: Yā Mūsā, her ki saña ẓulm itse sen anı ' afv eyle ve her kim senden kesilse sen andan kesilme, aña yoldaş ol ve her kim seni maḥrūm eylese sen aña nesne vir. Yā Mūsā, baña dahı dā-[154b]-yim ḳulluḳ eylegil ve bana şirk getürme. Yā Mūsā, her kim baña țā́ at eylese ve halḳdan medḥ ü șenā umsa ya' ní ḩalk anuñçün eyü kişidür desünler diyü ol kişi anları baña ortaḳ eylemiş olur. Yã Mūsā, diler misiñ kim benüm dostlarum ve feriştehlerüm seni seveler. Mūsā eyitdi: Beli yā Rab, benüm daḩı dilegüm oldur. Ḥaḳ Te ālā eyitdi: Yā Mūsā, sen dahı̆ beni ḳullaruma sevdür. Mūsā eyitdi: İlāhī, seni ḳullaruñ ki nice sevdürem? Ḥaḳ Te ālā eyitdi: Yā Mūsā, benüm ni` metlerümi cömerdligimimi ḳularuma eyit, tā ki anlar daḩı beni unutmayalar ve benden gayri kimseyi añmayalar ve baña eyü șanu șanalar. Yā Mūsā, diler misin ki saña ḳ̣yāmet güninde ' az̄āb itmeyem? Mūsā eyitdi: Beli dilerem. Ḥaḳ Te` ālā eyitdi: [Ḳ̂a $\left.{ }^{14}\right]$ Her gece yanıcak ve durıcaḳ dāyim beni añ, hiç̧bir ḥālde beni unutmayasın. Yā Mūsā, diler misiñ ki benüm düşmanum ve senüñ düşmānuñ seni țabulamaya? Mūsā eyitdi: Belī dilerem. Ḥaḳ Te ālā eyitdi: Yā Mūsā, benüm fariżalaru-[155a]-mı dāyim edā ḳıl. Mūsā eyitdi: İlāhī, benüm ve senüñ düşmānuñ kimlerdür? Ḥaḳ Tebāreke ve $T e^{e}$ ālā eyitdi: Yā Mūsā, benüm ve senüñ düşmānuñ

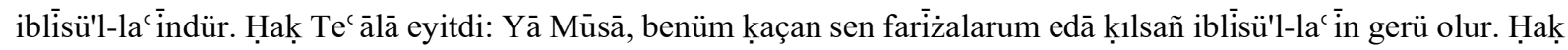

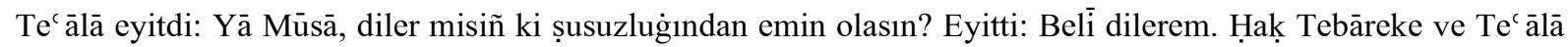
eyitdi: Yā Mūsā mü 'minler içün dāyim istiğfār eyle. Mūsā eyitdi: İlāhī, mü’minler içün nice istig̉fār ideyim? Ḥaḳ Tebāreke ve Te`ālā eyitdi: Yā Mūsā, her günde yigirmi beş kerre bu du'āyi oḳı. Estaǵfirullāhü'l-

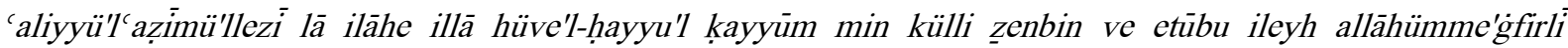
velivālideyye ve erhamhümā kemā rabbiyāni șagìiren ve'l-cemíc i'l-müslimine ve'l-müslimāti ve'l-mü 'minine ve'lmü 'mināti'l-ehyāa 'i minhüm ve'l-emvāti. Yā Mūsā, ḳanḳı kişi kim bu istiğfārı günde yigirmi beş kez dise ben ol kişiye yetmiş șıddīk șevābın virem ve dahı Ḥaḳ Te ālā eyitdi: Yā Mūsā, diler [155b] misiñ kim seni her ḥālde unutmayam? Eyitdi: Dilerem. Ḥaḳ Tebāreke ve Tecālā eyitdi: Yā Mūsā benden uṣanma. Yā Mūsā, diler misiñ kim halḳa muḥtāc olmayasın? Mūsāe eyitdi: Belī dilerem. Ḥaḳ Te`ālā eyitdi: Yā Mūsā, halkuñ mālına țama` eyleme. Yā Mūsā, diler misiñ kim ' amelüñ riyādan ḥalāṣ bulasın? Mūsā eyitdi: Belì dilerem. Ḥaḳ Te' ālā eyitdi: Hualḳdan medḥ ü șenā umma. Yā Mūsā, diler misiñ kim ḳyāmet güni terāzūda günāhuñ yengi gele? Eyitdi: Belì dilerem. Ḥak Te ālā eyitdi: Bāya yohsula müdārā eyle ve ḳoñşularuñ incündigine șabr u tahammül eyle. Yā Mūsā, diler

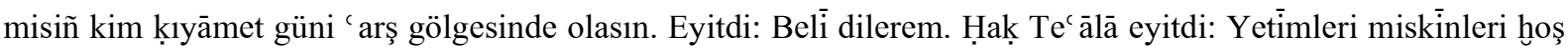
dutğıl. Yā Mūsā, diler misiñ kim ḳıyāmet[te] Muḥammed ḥavżından şerbet içesin. Eytidi: Belì dilerem. Ḥak Tebāreke ve Te`a ālā eyitdi: Hูațā ve günāh işleyene kỉn dutmag̉ıll. Yā Mūsā, diler misiñ ki ḳyāmet güni feriştehler arasında rüsvāy olmayasın. Eyitdi: Beli dilerem. Ḥaḳ Te`ālā eyitdi: [156a] Yā Mūsā, feriştehlerüñ ' aybın açmağıl. Yā Mūsā, diler misiñ kim ḳıyāmet güninde bitüdigi sāg elüñe vireler? Eyitdi: Belì, dilerem. Ḥaḳ Te ālā eyitdi: Yā Mūsā, elüñden geldikce mü'minlerüñ ḥācetin revā ḳılğııl. Yā Mūsā, diler misiñ kim rizgunna bereket ${ }^{15}$ ve ' āfiyet virem? Eyitdi: Belī, dilerem. Ḥaḳ Te`ālā eyitdi: Yā Mūsā, ābdesti gökcek alğıl namāzınçün. Yā Mūsā, diler misin kim dünyāda ve āḩiretde saña yardım idem? Eyitdi: Belì, dilerem. Ḥaḳ Te` ālā eyitdi: Yā Mūsā, hị̧̧bir kimsenüñ ḥaḳkında yavuz gelici itmegil. Ola ki kişi işidüb hāạtırı ḳala, melūl ola. Yā Mūsā, diler misiñ kim ḥūrìiere seni sevdürem ve uçmag̉ı saña müştāk eyleyem? Eyitdi: Belì, dilerem. Ḥaḳ Te ālā eyitdi: Yā Mūsāa, ahşsam ile yatsu arasında altı rek' at namāz ḳılg̀ıll. Yā Mūsā, diler misiñ kim cemī' -i halḳuñ yigregi olasın? Eyitdi: Belī, dilerem. Ḥaḳ Te`ālā eyitdi: Yā Mūsā, ‘ amelüñi benümle senüñ arañda ḳıl. Iraḳ kimse bilmesü[n]. Yā Mūsā, diler misiñ kim ḳıāmet gününde saña ḥisābuñı uzun itmeyem? Eyitdi: [156b] Belī, dilerem. Ḥaḳ Tecālā eyitdi: Yā Mūsā, koñşularuñ `ayb[ını] açmaġıl. Yā Mūsā, diler misiñ kim cemī` -i du`ālaruñı ḳabūl ḳılam? Eyitdi: Belì, diler[em]. Ḥaḳ Te`ālā eyitdi: Yā Mūsā, ḳarnuña ḥarām nesne ḳoyma. Bir kişi ki ḳarnına bir loḳma ḥarām ḳoysa benüm ḳatumda ḳırk gün ol kişinüñ du āsı ḳabūl olmaya. Yā Mūsā, diler misiñ ki benüm gazażabumdan ḩışmumdan emīn olasın? Eyitdi: Belī, dilerem. Ḥaḳ Te`ālā eyitdi: Yā Mūsā, elüñ altındağıları incitme ve anlara gażab itme. Yā Mūsā, diler misiñ ki seni müdām hayr ile zikr idem. Eyitdi: Belì, dilerem. Ḥaḳ Te ālā eyitdi: Yā Mūsā, ' ālimler meclisinde oturğıl ve anlaruñ meclisinden ırag̉ olma. Yā Mūsā, gice ve gündüz benüm hışmumdan emīn olmağıl, ḳorḳadurğıl. Mūsā eyitdi: Senüñ ḩışmuñ nedür? Ben ḳuluna bildür tā ki ben dahı andan șaḳınam ve anı bilem. Ḥaḳ

\footnotetext{
$14 \quad$ Kelimenin üstü çizilmiş.

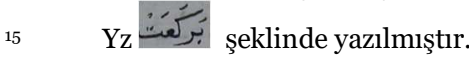


Te`ālā eyit- [157a]-di: Yā Mūsā, ḥarām nesne ile sevinmek. Yā Mūsā, diler misiñ ki ḩı̧̧ımıdan ve la' netümden emin eyleyem ve senden hoşnūd olam? Eger beni günde yetmiş kez ḳaḳıdursañ dahı̆ eyitdi: Beli dilerem. Ḥaḳ Te` ālā eyitdi: Yā Mūsā, ataña ve anaña mutī ol, eger kāfir dahı olursa. Zî̀ā cehennem odı ḳızarur ve yaliklenür. Müşrikler içün ve dahı atasın ve anasın azarlayanlar ve ribā ve ribā yapanlar içün ve dahı yā Mūsā, benüm raḥmetüm ve mag̉firetüm ve 'afvüm atasın ve anasın sevindürenler içündür. Yā Mūsā, her kim atasın ve anasın kendüden hoşnūd eylese ben anı yarlıgaram. Eger ol ḳulum günde yetmiş kez baña 'ạṣi olursa daḩı. Yã Mūsā, benüm ḩışmum atasın ve anasından şikāyet idenleredür. Yā Mūsā, her kim atasın anasın āzārlaya benüm ḩışmum ve la' netüm ol kişi üzerine vācibdür ol kişi ' ābid daḩı olursa. Yā Mūsā, her kim atasın anasın kendüden hoşnūd eylese benüm [157b] raḥmetüm ol kişinüñ üzerine vācibdür, ol kişi günāhkār daḩı olursa. Mūsā eyitdi: îlāhī, sen yigrek bilürsin ben anı bilmezem. Ḥaḳ Te` ālā eyitdi: Yã Mūsā, benüm ḩı̧̧mum ve gażabum ol kişidür ki ' ahdine durmaya ve emānete ḩyānetlıḳ ide. Yā Mūsā, ḳıyāmet gününde zebānīlere ol kişiyi yüzi üzerine sürüyüb tamuya bırag̉alar ve ag̉zına zaḳkūm ḳoyalar. Gözinden ve ḳulagiından çıḳa. Yā Mūsā, görseñ anları kim emānete hùānetlıḳ iderler ve ḳavline durmaz[lar] țamu içinde nice 'azāāb çekerler. Ṭamunuñ ag̉ulu yılanları ve çıyanları gövdelerine ve dillerine nice șoḳarlar. Dillerinden nice aṣılurlar ve boyunları ve burunlarını nice çıkarurlar. Yā Mūsā, diler misin kim ol 'azāblardan emin olasın? Mūsā eyitdi: İlāhì, nice dilemeyem ki beñzüm șarardı ve gövdem 'urber yüregüm ditredi ve dilüm dutuldı, gözlerüm görmez oldı ve ḳulaḳlarum işitmez oldı ve terlere garḳ oldum bu 'az̄ābları işidicek. [158a] Ḥaḳ $\mathrm{Te}^{c}$ ālā eyitdi: İtdügüñ ḳavli bozmaġıl ve emānete hıyānetlı̣ itmegil tā ki bu işitdügüñ 'azāāblardan emīn olasın, kurtulasın. Yā Mūsā, cehennemi saña vaṣf ideyim. Eger yedi gökleri ve yedi yerleri cehenneme bıraḳsalar bir deñize bir yüzük bıraḳmış gibi ola. Yā Mūsā, țamunuñ odları birbirinden gāayet 1sıdur. Şöyle ki eger țamu odundan bir çekirdek miḳdārı dünyāya düşe dünyāda ne ḳadar țaş var ise yanub kömür olaydı. Yeryüzünde hịçbir cānvār ḳalmayaydı. Yā Mūsā, eger țamu ehlinden bir kişi maşrı̣̂da ḳoyalardı mag̉rib halḳı ol kişinüñ isinden yanaydı ve yeryüzünde hị̧bir yaprak, ot bitmeseydi. Yā Mūsā, eger cehennemden bir kişi çıḳarsalar dünyā oduna bıraḳsalar yetmiş yıl dünyā odına yanub raḥatlığından bir yanına dahı dönmeyeydi. Yā Mūsā, cehennemüñ yedi țabaḳası var. Her bir țabaḳasında yetmiş biñ dere vardur. Her bir derede yetmiş biñ köşk var her bir [158b] köşkde yetmiş biñ ev var her bir evde yetmiş biñ tābu $t^{16}$ var. Her bir tābūda yetmiş biñ yılan ve çıyan var. Her bir yılanuñ uzunluġı elli yıllık yol miḳdāııur ve dahı yā Mūsā, her bir çiyanuñ büyüklügi Ṭūrir ${ }^{17}$ Ṭağı gibidür. Yā Mūsā, eger çiyanlaruñ ve yılanlaruñ birisi bir kimse[y]i șoḳsa acısı ḳıvrıla degin çı̣̣maya. Yā Mūsā, müşrikleri ve atasın ve anasın āzārlayanları ribā yiyenleri ve ribā işleyenleri ve zekāt virmeyenleri ve şücī içenleri ve zinā idenleri ve ḳoculuk idenleri șag̉u șag̉anları ve diñleyenleri ve nāḥak yere ḳan idenleri ve bühtān idenleri ve emānete ḥıyānetlık idenleri ve ' ahdine durmayanları ve ḥased idenleri ve kibr idenleri ve hạ̄[r]cı borc[1] olub vermayanları ol tābūtlara ḳoyaram. Ol yılanları ve çiyanları üzerlerine havāāe iderem. Tā ol kişiler bileler ki benüm kitāblarum ḥaḳdur ve benüm peyḡāmberlerümüñ ḳavli ḥaḳdur. Yā Mūsā, eger dünyāda ḳoculuḳ itmeyelerdi ve süci içmeyelerd-[159a]-i șag̉u șaġmayalardı ve ribā yapmayalardı her bir heftede üç kez yag̉mur yag̉duraydum. Her bir ayda bir kez ot bitüreydüm. Üç ayda bir kerre ḳoyun ḳuzulayaydı. Dükeli ḩalḳ 'azaābdan emin olaydı. Gökden bereket ḳapusı açılaydı. Yā Mūsā, eger kocuları göreydük kim ölüm eskilügi nice çekerler ve şehādet getürmekde diller nice dutulur. Yā Mūsā evvel țamuya giren ḳocular ola ve șag̉u șag̉anlar ola ve ribā yiyenler ola ve dilleri țamu yılanlarınuñ ag̀zı içinde ola. Yā Mūsā, dükeli feriştehler ve ol yılanlar ve șag̉u șag̉anlara ve diñleyenlere la net iderler. Yā Mūsā, ḳoculuk itme ve diñleme tā ki günāhda etlerüñle şerīk olmayasın. Yā Mūsā, ribā yimekden șaḳın zīrā benüm la` netüm ribā yiyenleredür ve yazanlara ve țanı̣̣ olanlaradur. Yā Mūsā, benüm la' netümden șaḳın! Zïrā bir kişiye bir kez la' net itsem ol kişinüñ 'ömri oldugiunca 'ibādet itse, orūc dutsa, șadaḳa virse dahı gökden inen kitāblaruñ küllisin [159b] oḳusa cemí'-i ' ālem şefíc olsa uçmaḳ ḳoḳusı ol kişinüñ burnına ebedī girmeye ve raḥmet bulmaya. Yā Mūsā, zekāt virmedük māldan yimegil ve zekāt virmeyen kişiyle yiycek yimegil ve içmegil. Kim ol kişi uçmag̉uñ berekātın yaḳmışdur ve dahı yā Mūsā, benüm aduma yalan and içme. Zīrā benüm aduma yalan and içse ben ol kişịi[yi] oda yaḳaram. Yā Mūsā, iblīisden ve cühūdlardan gayri hịçbir nesneye la' net itme. Zìrā girü ve la' net idene gelür. Yā Mūsā, cānāverlere la' net itme kim ben anları ṣaḳlaram ve anlara yardım iderem. Yā Mūsā, gazazab ḳılma kim gazazab şeyṭāndur ve şeyțān oddandur. Yā Mūsā, gażab ỉmānı

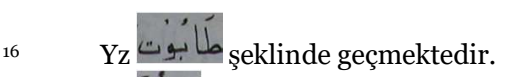

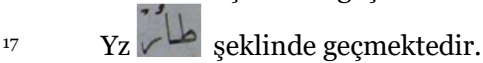


yuyar. Nitekim șabr bāli yuyar. Yā Mūsā, yalandan șaḳın kim aduñı șalihlerle yazam. Eger șaḳınmazsañ aduñı șāliḥlerden yuyam ve ehl-i nifāḳdan yazam. Yā Mūsā, benden ḳork. Zīiā benden ḳorḳmayanı sevmezin ve raḥmet itmezin. Yā Mūsā, Beni İsrā 'ìl'e eyit [160a] benden ḳorḳsunlar ve benüm ḳorḳumdan gaāil olmasunlar. Zïrā her kim gice yata ve erte ḳalḳa. Benüm ḳorḳumdan emin olayın. Ol kişiye bir nesne idem ki cemíc -i halḳ kıyāmet gününde ve dünyāda heybetinden ġayret olalar. Yā Mūsā, her kim șadaḳa virse gizlü ve āşikār benü[m] hoşnūdlugium içün ben ol kişi üzerine gice ve günden raḥmet șaçusın șaçam. Yā Mūsā, her kim ḳādir olduğı nesne[y]i ‘ afv itse ben ol kişiye günde yetmiş kez naz̧ar eyleyem. Ol kişi[y]i țamu odı yaḳmaya. Yā Mūsā, bir ölüyi kim ki yusa ol kişinüñ günahların yuyam, arıdam ve her kim bir ölüye sini kazsa ben dahı̆ ol kişiye uçmaḳda bir köşk yapam ve her kim bir ölüye kefen șarsa ben ol kişiye uçmaḳ hil' atlerinden ḩil' at geydürem ve her kim bir cenāze getüre ben ol ḳulı țamu odundan azād eyleyem. Ḳıyāmet gününde anuñ boynunı od yaḳmaya. Kim ki bir ölü[y]i sinlesine indürse ol kişiyi cemī -i günāhlarından arına, anadan țog̀mış gibi ola. Her kim bir ölünüñ üzerine topraḳ dökse ḳyāmet gününde aña uçmak ța āmın yedürem ve her kim bir yalıncağı țonatsa ben aña uçmaḳda dībā geydürem. Yā Mūsā, ḳonıg̀ı ag̉ıllag̉ıl eger kāfir daḩı olursa. Yā Mūsā, ḳaçan eve ḳonuḳ gelse rızg̣la bile gelür, ḳaçan gitse ev ıssınuñ günāhları bile gider. Yā Mūsā, bir kişinüñ evine benüm raḥmetüm ve bereketüm ḳonuḳlar ile gelür. Yā Mūsā, benüm ḳonuggumı dahı senüñ ḳonuguuñ gibi ag̀ırla, ' izzet eyle. Mūsā eyitdi: İlāhī senüñ ḳonuguuñ ve benüm ḳonugium kimdür? Ḥaḳ Te`ālā eyitdi: Yā Mūsā, senüñ ḳonuguuñ oldur kim evüñe getdüñ oḳuyasın ve benüm ḳonug̉um oldur kim oḳumadın kendü añulur. Yā Mūsā, bir kişi görseñ rıżgunda berekāt var, teninde ṣıhhat var, baña tạa at itmez, baña 'ạși olur bilgil ki ben ol kişiyi helāk idecegüm geldi. Yā Mūsā, [161a] bahîil olma ve yalanc1 olma ve mesāvī söyleme. Yā Mūsā, bahîllerle ve yalancılarla ve mesāvī söyleyenlerle șoḥbet eyleme. Yā Mūsā, işledügüñ işlerde ivme kim ivmek şayțāndur. Meger üç işde evmek gerek. Eve ḳonuḳ gelicek ag̉ırlamaḳda, ḳı og̉lan bālig olduḳdan șoñra ere virmekde, üçünci ölüyi defn itmekde, dördünci ben saña buyurduguum nesneleri sen dahı ḩalḳa bildür. Ben seni yıg̉dugüm nesneleri sen daḩı halḳ[a] bildür. Yā Mūsā, ergen kişileri ever kim og̉lancıḳları olsun. Tā kim ḳyāmet gününde atasına anasına şefāe atci ola. Yā Mūsā, ötegü olma ve ötegülerle șoḥbet eyleme. Yā Mūsā, her gün ölümi añmaḳdan hạalī olma ve yaraḳlan kim zỉrā melekü'l-mevt günde yetmiş kez ḩalḳuñ eceli defterine naẓar ider. Hị̧̂bir nesne bilmez ki eceli ne vaḳtin gelür. Yā Mūsā, nefsüñi düşmān țut, ol vaḳit ki kendü eksük arzūsun isteye. Yā Mūsā, ḳaçan kim emīn olsuñ benden ḳorḳ. Zīrā yā Mūsā, benüm mag̉firetüm sebebi țā́ atdur. [161b] Yā Mūsā, sen beni añ tā ki ben daḩı seni añam. Yā Mūsā, eger sen Ḥaḳ ḳatında añarsañ ben dahı seni feriştehler ḳatında añam. Yā Mūsā, eger sen benden ḩalḳ ḳatında şikāyet iderseñ ben dahı senden feriştehlerüm ḳatında şikā[yet] eyleyem. Mūsā eyitdi: İlāhī ben senden nice şikāyet ideyim ve kime şikā[yet] idem? Ḥaḳ Tebāreke ve Te aalā ḳaçan ki senüñ māluña veya nefsüne bir mușỉbet yetişe halḳa cüz ü nizāc eyleseñ taḥkịk yā Mūsā benden şikāyet etmiş olursın. Yā Mūsā, eger mü’minlerüñ günāhlarını mușỉbet virmegli ki yarlıgamaḳ dilesem ebedi atañ Âdem'i günāha mübtelā itmeyeydüm ve Ya' kụub' ${ }^{18}$ gözsüz itmeyeydüm ve Eyyūb'[1] rence giriftār itmeyeydüm. Mūsā eyitdi: İlāhî, Âdem'üñ ve Ya 'ḳūb'uñ ve Eyyūb'uñ [günāh1] ne idi? Ḥak Te`ālā eyitdi: Yā Mūsā, Âdem'üñ günāhı ol idi ki benüm buyurduguum șıdı ve bug̉day yedi ve Ya kuūb'uñ günāhı ol idi ki bir gün deve boġazladı, yalñuz yedi. Og̉lıyla ḳızıyla ḳoñşularına virmedi. Anlar bāy olduḳlariyçün ve Eyyūb'uñ [162a] günāhı ol idi ki bir gün ḳoyun bog̉azladı, og̉lıyla ḳızıyla yedi, halāyıḳa virmedi. Mūsā eyitdi: İlāhi, Âdem bigi dostuñı bir günāhdan ötüri yüz yıl agglatduñ. Bizüm ḥālümüz nice olur? Ḥaḳ Te`āāà eyitdi: Yā Mūsā, dostlaruñ günāhı dosta ag̉ır gelür. Mūsā eyitdi: İlāhî, diler misüñ saña ḥaḳ nesne șoram? Ḥaḳ Te ālā eyitdi: Ḳorḳmaġıl. Mūsā eyitdi: İlāhî, ḳanda olursın? Ḥaḳ Te`ālā eyitdi: Yā Mūsā, berhiz-kār ḳulumuñ göñli içinde oluram. Mūsā eyitdi: Berhīz-kār ḳuluñ kimdür? Ḥaḳ Te`ālā eyitdi: Ol kişidür ki ḥarām ḳorḳusından ag̉laya ve ḥelālden dahıı șaḳına. Mūsā eyitdi: İlāhì, yerüñ ve mekānuñ ḳandadur? Ḥaḳ Te ālā eyitdi: 'Arşdan dahı öte anda kim cihet yoḳ, mekān yoḳ ve 'arş dahı bilmez kim ben ḳanda oluram. Mūsā eyitdi: İlāhì, senüñ hażretüñde kim

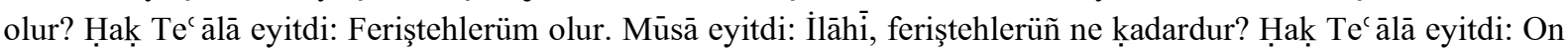
iki bölükdür. [162b] Og̉lanları ve perī ve şeyâț̣in ve uçar ḳuşlar ve yürür geyikler ve ne ḳadar cānāverler ve ḥayvānlar ve ḳum ḳayır varsa on iki anlarcadur çoḳluḳda. Mūsā eyitdi: İlāhî, senüñ ḳatuñda mü'min ḳulun mı sevgilidür yohssa ferişteler? Ḥaḳ Te ālā eyitdi: Yã Mūsā bir mü'min ḳularum ki șâliḥ ola. Benüm ḳatumda ol ḳulum

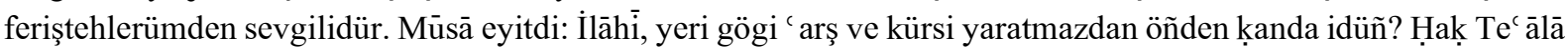

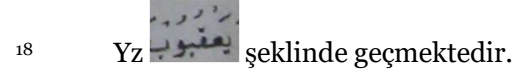

Adress

Kirklareli University, Faculty of Arts and Sciences, Department of Turkish Language and Literature, Kayalı Campus-Kırklareli/TURKEY e-mail: editor@rumelide.com 
eyitdi: Yā Mūsā, berrāk incüyi ben 'arşdan ve kürsīden dahı öñden yaratmış idüm. Ol incünüñ büyüklügi yüz biñ yıllıḳ yol idi. Mūsā eyitdi: İlāhî, ol incü şimdi ḳandadur? Ḥaḳ Te`ālā eyitdi: Yā Mūsā, ol incüyile bir kelime söyleşdüm benüm ḳorḳumdan ditredi, eridi, su oldı. Andan șoñra 'izzet naz̧arıyla bir naẓar itdüm, ḳaynadı dütün çıḳdı ve mevc urdı, göbegünden yerleri yaratdum ve mevcinden țaggları yaratdum ve ḳalanı ol șahrā daşıdur ki Beytü'l-muḳaddes'dedür. Ḳıyāmet [163a] güni ol daşdan yerin ḳıyāmet yaradısaram. Ol yerüñ üzerinde țurub 'adl idiserem. Zālimlerden maẓlūmlaruñ intikāmın alısaram. Mūsā eyitdi: İlāhī, ol incüyi yaratmazdan evvel ḳanda idüñ? Ḥaḳ Te ālā eyitdi: Ḳudretüm üzerinde idüm. Nitekim şimdi ḳudretüm ile ḳuşları hevā üzerinde dutaram ve bulutları gökyüzünde dutaram. Ḳudretüm ile ḳudret ile dururum. Mūsā eyitdi: İlāhỉ ḳaçandan berü Tañrılıḳ idersin? Ḥaḳ Te`ālā eyitdi: Yā Mūsā, derin ' ilmümden ve gizlü ḳudretümden su 'āl idersin. Yā Mūsā, eger benüm raḥmetüm gażabumdan ziyāde olmayaydı seni oda yaḳaydum. Mūsā eyitdi: Yã İlāhì, niçün? Ḥaḳ Te ālā eyitdi: Anuñçün kim sen benüm bidāyetümden ve nihāyetümden șorarsın. Ben ol Tañri'yam kim benden öñdin nesne yog̀di ve ben ebedü'l-ābād Tañr'yam. Benden șoñra nesne ḳalacaḳ degüldür ve dükeli nesnenüñ evveli benem ve benüm evvelüm yoḳdur ve dükelinüñ ahiri var, benüm āhirüm yoḳ. Mūsā [163b] eyitdi: İlāhỉ dilerem ki sābık 'ilmüñden bilem ve sen șaburlu Tañrı'sın, uyumazsın yimezsin, içmezsin. Ḥaḳ Te`ālā eyitdi: Yā Mūsā, bu deñli 'ālemi yaratmazdan öñdin biñ şehir yaratdum. Her bir şehrüñ büyüklügi bu dünyaca idi. Yā Mūsā, ol seksan biñ şehrüñ ḩardal dānesiyle doldurdum. Andan bir yeşil ḳuş yaratdum. Ol ḳuşa eyütdüm ki bu şehrüñ içinde olan hardal gördüñ mi? Dükelisi senüñ rızġundur, țur yeñil, didüm ve ḳaçan bu ḩardal dāneleri dükene, sen ol vaḳtin öleceksin, didüm. Ol ḳuş dahı ol seksan biñ şehir tọlusı günde bir dānesini yerdi. Âhir gördi ki hardal eksilmege başladı yılda bir dāne yer oldı. Fi'l-cümle ol seksan biñ şehir țolusı ḩardal yedi ve ḳaçan ki bir dāne hardal ḳaldı, ag̉zına aldı ve ag̉ladı eyvāh baña eyitdi ecelden, ölümden ve dahı ol ḳuş eyitdi: İlāhi, baña bunca uzun ` ömr virdüñ ve çok rızk virdüñ, imdi yā Rabbī, ölüm acısın baña gegez eylegil kim ben bir dāne hardal yedügümce [164a] saña yetmiş kez tesbihh oḳımışam, didi. Andan șoñra ol şehrüñ her birinde yetmiş biñ kişi yaratdum. Anlar ādem ve ferişteh degül idi. Bir dürlü ḩalḳ idi ve her bir kişiye yetmiş biñ yıl `ömür virdüm. Her bir yıllı, elli bu dünyā yıllarınca idi. Andan ol yetmiş kişiden bir kişi baña 'āṣi oldı. Ben dahı ol bir kişinüñ günāhından ötürü ol yetmiş biñ şehri birbirine urdum ve dükeli halḳııı helāk eyledüm. Mūsā eyitdi. İlāhi, ol bir kişinüñ günāhından ötürü yetmiş biñ şehri birbirine urduñ ve dükeli halḳını helāk eyledüñ. Ben ḳuluña bildür. Ḥaḳ Te ālā eyitdi: Ol kişinüñ günāhı ol idi ki kavmine eyitdi: Hayır bendendür ve şer sendendür. Ve dahı altı yüz biñ yıldan șoñra habibüm Muhammed nūrın yaratdum. Andan ol nūr yidi biñ yıl benüm ḳarşumda baña 'ibādet eyledi, namāz ḳıldı. Andan ṣoñra benüm nūrumdan bir avuç nūr-1 Muhamed nūrı üzre șaçdum ol nūr baña secde ḳıldı. Ol secdeden ötüri erte namāzın vācib ḳıldum. Andan ol nūr [164b] girü ḳarşımda durdı, yidi biñ yıl baña 'ibādet eyledi. Andan ol nūra benüm nūrumdan hil' at geydürdüm. Ol nūr dahı baña secde itdi. Ol secdeden ötürü öyle namāzın vācib ḳıldum. Andan altı yüz biñ yıldan șoñra 'arşı yaratdum. Andan bir ferişteh yaratdum. Ol bir feriştehe buyurdum ki ' arşı götüre. Nice kim cehd itdi götüremedi. Andan bir ferişteh dahı yaratdum. Anlar dahı götüremedi. Andan dört ferişteh yaratdum anlar dahı nice kim cehd itdiler götüremediler. Andan șoñra bir ḳarınca yaratdum ol ḳarıncanuñ büyüklügi beş barmak miḳdārı idi. Andan ḳarıncaya buyurdum ki ' arşı götüre. Andan ol ḳarınca dahı arşuñ altına girdi. Bir kez șıdk ile Bismillāhirraḥmānirrahìm tevekkeltü 'ale'l-lāh va'teșamtü billāhi velā ḥavle velā ḳuvvete illā billāhi'l- 'aliyyi'l'azīim diyicek 'arşi götürdi. Andan Yā Mūsā, ben feriştehlerüme eyitdüm: Eger siz dahı beni ol ḳarınca żikr itdügi gibi zikr itseñüz idi ol ḳarınca ḳuvveti [165a] gibi size dahı ḳuvvet vireydüm. Siz dahı ol ḳarınca gibi ‘arşı götüreydiñüz. Andan șoñra 'arş nūrından kürsi yaratdum ve kürsì nūrından güneşi yaratdum ve güneş nūrınuñ altı bahşından ayı yaratdum. Yā Mūsā, ' arş u kürsī ve ay ve güneş dükeli Muhammed nūrınuñ on baḩşınuñ bir baḩ̣ından yaratdum ve Muḥammed nūrın kendü nūrumdan yaratdum. Yā Mūsā, andan șoñra uçmag̀ yaratdum gevherden ve la' lden ve incüden ve yāḳūtdan ve mercāndan ve altundan ve gümüşsen ve uçmaḳ içinde ol nesneleri yaratdum ki gözler gördigi yoḳ ve ḳulaḳlar işitdügi yoḳ ve ādem og̣lanınuñ göñlünden ve huayālinden geçdügi yoḳ. Andan șoñra țamuyı yaratdum kendü ġażabumdan ve ḳahrumdan. Yā Mūsā, 'āṣilerden ve zālimlerden anuñla intiḳām alub andan beriyyeleri yaratdum. Oddan andan on biñ ādem yaratdum. Atañuz Âdem'den evvel ol beriyyeler Âdem ile düşmān idi. Ol beriyyeler dükeli oldılar. Andan ol ādemler on biñ yıl yaşadı. On biñ yıldan șoñra atañuz Âdem'i yaratdum. Yā Mū-[165b]-sā șaydugımı ve hisāb itdügimi kim ne vaḳtin berü Tañrılıḳ iderem ve ne vaḳtin berü Tañrı'yam. Andan Mūsā secdeye vardı uș̣̣ı gitdi. Yedi günden șoñra başın ḳaldurdı, eyitdi: İlāhī, tevbe ḳıldum ayruḳ bunuñ gibi nesneden ṣormayam. Evet ġayrī nesneden șoram. Mūsā eyitdi: Îlāhî, ḳullarundan 
saña yaḳın kimdür? Ḥaḳ Te`ālā eyitdi: Ol kişidür kim dükeli ḩalḳdan artuḳ ` ibādet ve dükeli ḩalḳdan kendü nefsin eksük bile. Mūsā eyitdi: Ol kişinüñ ‘ alāmeti nedür? Ḥaḳ Te` ālā eyitdi: Ṭā' ati çoḳ ide ve daḩ ḳorḳa ki țā‘ ati ḳabūl olmaya dah̆ı ḥarām nesneden ḳorḳa ve ḥelālden daḩı șaḳına ve daḩı țấ at[i] ve hayrin halḳ̣dan gizlü duta. Mūsā eyitdi: İlāhī, ol ḳullaruñ birin baña göster. Ḥaḳ Te ālā eyitdi: Ķaçan bir mü 'min görseñ kim tevāżu ${ }^{19}$ eyler ve az söyler ve ḳarnın aç dutar. Şöyle ki yemek yemegi elinden gelür ve dahı nefsi arzūsın düşmen dutar. Nitekim yavuz günāhlardan șaḳınur ve dahıı halḳı öger kendü nefsin horlar ve dahı açlar doyurur kendü [nefsin $]^{20}[166 \mathrm{a}]$ aç dutar ve dahıı yalıncağı donatdur ve kendüyi yalıncaḳ dutar ol ḳulum baña dükeli ḩalḳdan yaḳundur. Mūsā eyitdi: İlāhí, eger bu șifatlu kişiye uggrasam bilmesem nice idem? Ḥaḳ Te ālā eyitdi: Ķaçan bir mü’mini görseñ ki mü’minlerüñ günāhın, ma`șiyetin, guușșalanur şöyle kim kendü günāhı içün müslümānlaruñ hayrına sevine. Nitekim kendü ḩayrına sevinür bilgil kim ol kişi dükeli ḳullardan baña yaḳındur. Mūsā eyitdi: İlāhî, ol ḳulları bulmayacaḳ olursam nice idem. Eyitdi: Yā Mūsā, ḳaçan bir mü ’min görseñ kim ḳaḳıyana benüm içün ḳaḳır ve ḩoşnūd olsa benüm içün hoşnūd olur ve dahı söylese benüm içün söyler ve benüm içün epsem olur bilgil kim ol kişi benüm dostumdur. Mūsā eyitdi: İlāhi, ḳullaruñda düşmānuñ kimdür? Ḥaḳ Te`ālā eyitdi: Ol kişidür ki ḳaḳısa kendü nefsin arzūsı içün epsem olur, söylese kendü nefsi arzūsı içün söyler benüm ḩoşnūdlugium gözetmez ve ḳaçan mālına, og̀lına ve [166b] ḳızına mușibet degse çok guușsalanur benüm ḳażāma boyun virmez ve ne kim ḳazā gelürse Ḥaḳ'dan geldi dimaz eger bir Müslümān ölse veya bir Müslümān'a muṣibet degse anuñçün hiç ḳayırmaz sevinür, yā Mūsā bilgil ki ol kişi benüm gāayet düşmenümdür. Mūsā eyitdi: İlāhỉ, beni bir ' amele ḳulag̉uzla ki ol ' amel sebebiyle benden hoşnūd olsın. Ḥaḳ Te āalā eyitdi: Eger benüm hoşnūdlug̉um isterseñ dünyā bāylıg̉ından geçmek gereksin. Dünyā 'izzetin düşmān dutmaḳ gereksin yohssullug̉ı sevmek gereksin ve dünyā horluġını ḳabūl itmek gereksin. Yā Mūsā, eger bu nesne[y]i kabūl idecek olursañ dünyā senüñ ḳatuñda hor ola ve sen benüm ḳatumda 'azīz olasın. Mūsā eyitdi: İlāhì, dünyā arzūların niçün yaratduñ? Ḥaḳ Te` ālā eyitdi: Kullarum ṣınamaḳ içün yaratdum. Zỉrā her kim dünyā arzūların terk idüb āhiret arzūlarını iḩtiyār itse ol ḳulum benüm ḳatumda 'izzetlüdür. Mūsāe eyitdi: İlāhī, senüñ ḳatuñda ḳanġı kişi mestūrdur? Ḥak [167a] Te ālā eyitdi: Ol kişidür kim az yiye, az söyleye. Mūsā eyitdi: İlāhi, ḳang̀ı ḳuluñ ḩalḳuñ yigregidür? Ḥaḳ Te`ālā eyitdi: O kişidür kim halḳa fāyidesi doḳuna. Mūsā eyitdi: İlāhī, ḳanġı ḳuluñ senden rraḳdur? Ḥaḳ Te`ālā eyitdi: Ol kişidür kim 'izzeti mālıyla ve ḳavmi ve hıṣımla ola. Mūsā

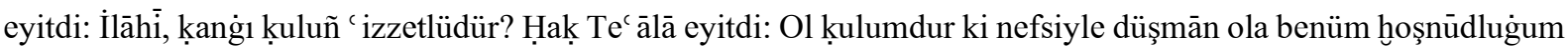
içün. Mūsā eyitdi. Kanğı kuluñ göñli nūrludur ve șāî̉dür? Hak Tebāreke ve Te`ālā eyitdi: Ol kişidür kim benüm heybetümden dāyim ḳorḳa. Mūsā eyitdi: İlāhī, ḳanġı ḳuluñ göñli ḳatıdur? Ḥaḳ Te ālā eyitdi: Yalancılaruñ. Mūsā eyitdi: İlāhī, benden hoşnūd oldıñ mı? Ḥaḳ Te`ālā eyitdi: Yā Mūsā, ḳaçan kim ḳoñşularuñ senden ḩoşnūd olalar ben dahı ben daḩı senden ḩoşnūd olam. Mūsā eyitdi: İlāhì, baña bir nesne ögret kim andan baña fāyide ola. Ḥaḳ

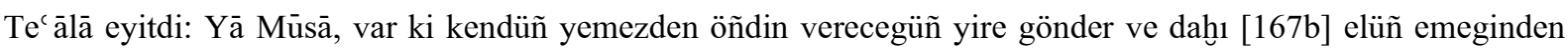
yegil ve dünyāda az nesneye ḳanā`at eylegil ve ne deñlü țamu odına ḳatlanabilürseñ aña göre günāh işlegil ve dünyāda duracaġuñ deñlü ḳazanġıl berrāḳ yegil. Yā Mūsā, halḳını esrige tā ben seni esirgeyem. Yā Mūsā, gegezlık eyle tā ben dahı senüñle gegezlık eyleyem. Yā Mūsā, halḳı ḩayr ile añğıl ve 'ayb ört. Tã ben daḩı senüñ 'aybuñ örtem. Yā Mūsā, og̉lancuḳlara şefkatlü dāye bigi olğıll. Kendü og̉luñ gibi ḩıdmet eylegil ve dünyāyı müsāfir gibi konub küçücek menzili bilgil ve mușibetlere șabr itgil ve mușibetden kimseye şikāyet eyleme ve dünyā hoşlugìndan sevinme. Yā Mūsā, müttakịilere ța ām yedürgil ve anlaruñla bile yegil. Her işde müttakịilere danış่̧ıl ve anlara ḳoñşu olğıl ve dahı făcirler ve müfsidler șoḥbetinden ḳaç่g̀l ve anlaruñla ḳoñşu olmaġıl. Göñlüñ ḳatı olmasun. Yā Mūsā, hak sözi tọgru söyle eger kendü nefsüñe ziyān dahı olursa. Zīiā her yirde ve her işde benden [168a] gayrri yardumcı yoḳdur. Yā Mūsā, bu du' à’ı çok oḳug̣ıl. "Sübhānallāhi ve'l-ḥamdülillāhi velā ilāhe illāllāhu vallāhu ekber velā ḥavle velā ḳuvvete illā billāh'il' aliyyi'l-'azịm sübḥāne men ta'azzür bi'l-ḳudreti ve'l-bakāa ve kahra li' ibādi bi'l-mevti ve'l-fenä" Yā Mūsā, bu du'à'ı günde bir kerre oḳuġıl. "Allāhümme bārik fi'l-mevti ve

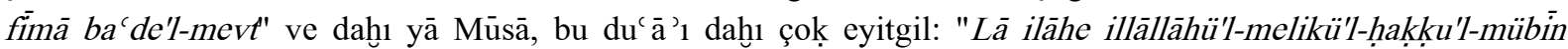
Muhammedün resūlallāh șādıḳu'l-va' dü'l-eminn" ve dahı yā Mūsā, saña buyurdugum nesneleri ve saña virdügüm hịçbir peyġāmbere virmedüm. Yã Mūsā, saña buyurdug̉um nesneleri işleme. Yarın ḳıyāmet güninde ol ucından utanmayasın. Yā Mūsā, benüm mekrümden emin olma ve raḥmetümden ümídüñ kesme. Yā Mūsā, sen benümle ol

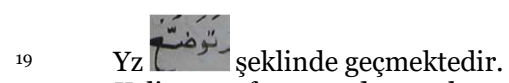

20 Kelime sayfa sonunda yer almasına rağmen 166a'nın başında yer almamaktadır.
} 
ben dahıı senüñle olam. Yā Mūsā, selāmum ve raḥmetüm senüñ üzerüñe olsun ve daḩ halḳumuñ yigregi Muhammed özine olsun. Âmin yā Rabbi'l-c ālemin ve yā ḩayre'n-nāṣırīn ve'l-ḥamdülillāhi [168b] rabbi'l- cālemīn ve'l- aaḳıbeti lilmüttakịin velā ' udvāne illā 'ale'z-ẓālimīn ve șallallāhu 'alā seyyidinā Muḥammedin ve ālihi ve șaḥbihi ecma' in bi-raḥmetike yā erḥame'r-rāḥimin.

Bu kitābı yazanuñ ismi Kaya

Cümle maḩlūḳuñ hāàki olmuşdur gedā

Raḥmet aña kim du'ā eyle aña

Dahı cümle aḳrabasına ü hem aña

Oḳuyanı yazanı diñleyeni

Raḥmetüñle yarlığag̀ıl yā Ġani

Bu faḳirüñ hakḳ̣ına kim ‘aşḳ ile

Bir du ${ }^{(} \bar{a}^{\prime}-1$ ḩayr iderse șıdḳ ile

Ḥaḳ Te`ālā raḥmet itsün anlara

Hem oḳuyub müstemi` olanlara

Cümlenüñ ḥaḳkında söz bitdi hemīn raḥmet itgil yā İlāhe'l- ālemīn.

\section{Kaynakça}

Aşçı, D. U. (2012). Mûsâ-nâme (İnceleme- Transkrisiyonlu Metin-Çeviri-Dizin-Tipkıbasım), Palet Yayınları: Konya.

Can, Ş. (2016). Mesnevî Hikâyeleri, Ötüken Neşriyat: İstanbul.

Canım, R. (2012). Divan Edebiyatında Türler, Grafiker Yayınları: Ankara.

Demir, Ş. (2003). Mitoloji Kur'an Kıssaları ve Tarihi Gerçeklik, Beyan Yayınları: İstanbul.

Devellioğlu, F. (1998). Osmanhca-Türkçe Ansiklopedik Lûgat, Aydın Kitabevi Yayınları: Ankara.

Gökcan Türkdoğan, M. (2010). "Klasik Türk Edebiyatında Kur'an Kıssalarını Konu Alan Mesneviler", Uluslararası Sosyal Araştırmalar Dergisi Klasik Türk Edebiyatının Kaynakları Özel Sayısı, Prof. Dr. Turgut Karabey Armağanı, C. 3, S. 15, s. 64-92.

Hazer, D. (2007). "Kur'ân-ı Kerim Kıssalarının Edebî Değeri Hz. İbrahim Kıssalarını Vaka-ZamanMekân-Şahıs Unsurları Açısından Bir Değerlendirme", İslami İlimler Dergisi I. Kur'an Sempozyumu, İslami İlimler Dergisi Yayınları: Çorum. s. 205-218.

Karaçizmeli, M. (2018). "Kur'an'da Geçen Yusuf ve Musa Kıssalarının Benzer ve Farklı Yönleri", Fatih Sultan Mehmet Vakıf Üniversitesi Sosyal Bilimler Enstitüsü, Yüksek Lisans Tezi, İstanbul.

Kıssa-i Musa (A. S.), Amasya Beyazıt İl Halk Kütüphanesi, Numara 509/4.

Levend, A. S. (1998). Türk Edebiyat Tarihi I. Cilt, Türk Tarih Kurumu Basımevi: Ankara.

Levend, A. S. (2016). "Dinî Edebiyatımızın Başlıca Ürünleri", Eski Türk Edebiyatı Araştırmaları, C. II, Türk Tarih Kurumu Yayınları: Ankara.

Ölker, G. (2013). Kıssa-i Mûsâ 'Aleyhi's-Selâm Ma'a Fir'avn Kavmihi Min Ehli'l-Küfr ve'z-Zalâm, Palet Yayınları: Konya. 
Redhouse, S. J. (2011). Turkısh and Englısh Lexıon New Edıtıon, Çağrı Yayınları: İstanbul.

Sağlam, H. (2019). "Kıssa-i Mûsâ (A. S.) (Söz Dizimi İncelemesi)", Yüksek Lisans Tezi, Marmara Üniversitesi Türkiyat Araştırmaları Enstitüsü: İstanbul.

Şengül, İ. (1994). "Kur'an Mesajını Ulaştırmada Kıssaların Önemi", 1. Kur'an Sempozyumu TebliğlerMüzakereler, Bilgi Vakfı Yayınları: Ankara.

Uçman A. (2019) Müzekki'n-Nüfûs Eşrefoğlu Rûmî. İnsan Yayınları, İstanbul: 2019.

Uğur, A. (2019). "Yazıcıŏglu Ahmed Bîcân Efendi ve Evâru'l-Âşıîn Adlı Eseri (İnceleme-Metin)", Marmara Üniversitesi Türkiyat Araştırmaları Enstitüsü, Doktora Tezi, İstanbul.

Yılmaz E.; Demir N.; Küçük M. (2013). Kısas-ı Enbiya, Türk Dil Kurumu Yayınları: Ankara.

https://kuran.diyanet.gov.tr/tefsir E. T: 13.01.2020. 
228 / RumeliDE Journal of Language and Literature Studies 2020.18 (March)

Evaluations on Kıssa-i Mûsâ narratives and an example of Kıssa-i Mûsâ / H. Çavuşoğlu (pp. 206-229)

\section{Ekler:}

$146 \mathrm{~b} / 147 \mathrm{a}$

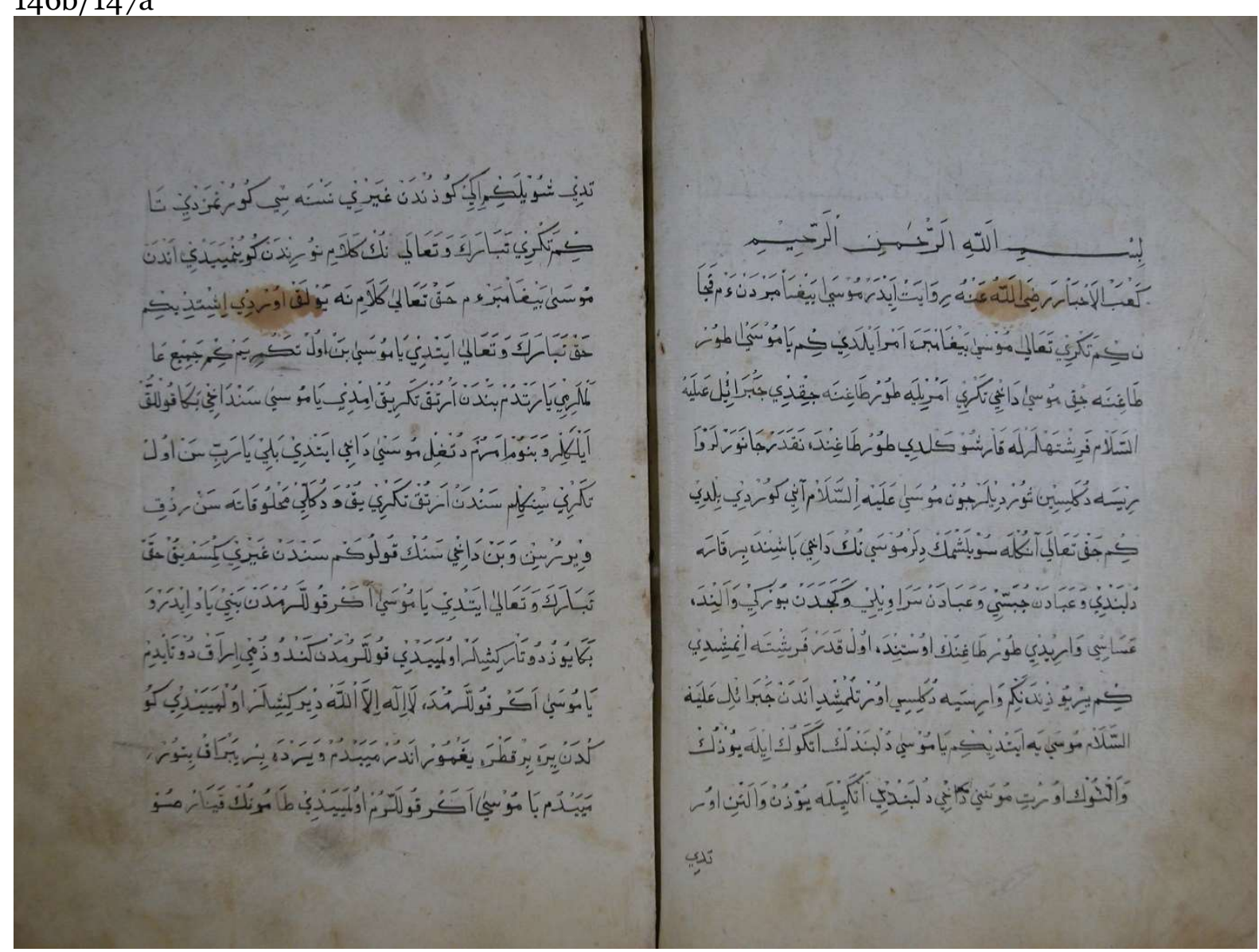




\section{$147 \mathrm{~b} / 148 \mathrm{a}$}

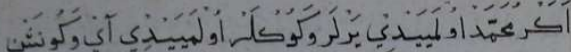

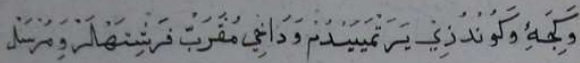

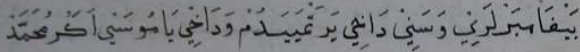

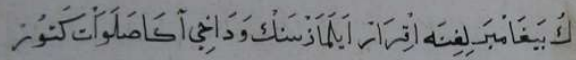

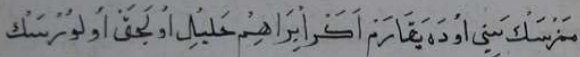

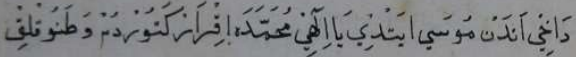

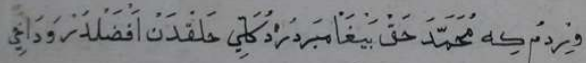

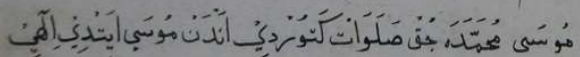

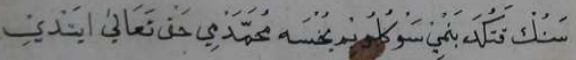

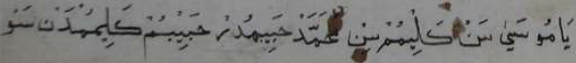

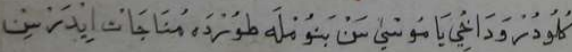

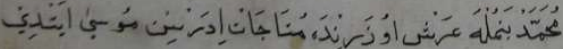

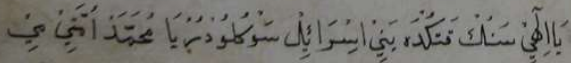

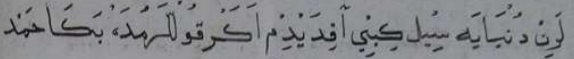

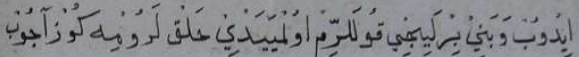

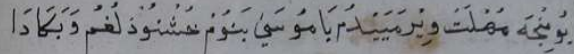

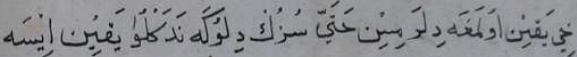

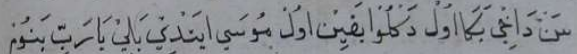

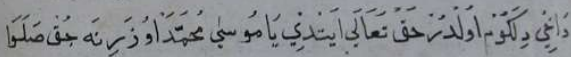

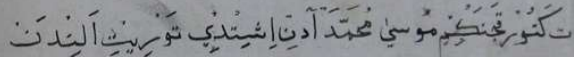

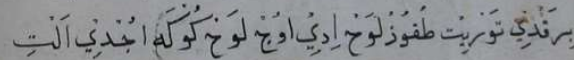

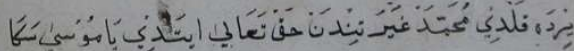

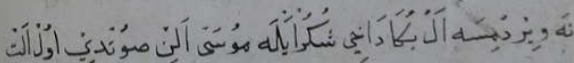

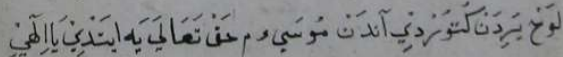

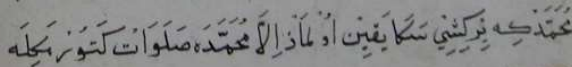

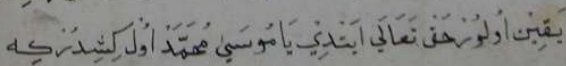
$\sqrt{1}$ 